117) Nordic Council of Ministers

Potentials for reducing the health and climate impacts of residential biomass combustion in the Nordic countries

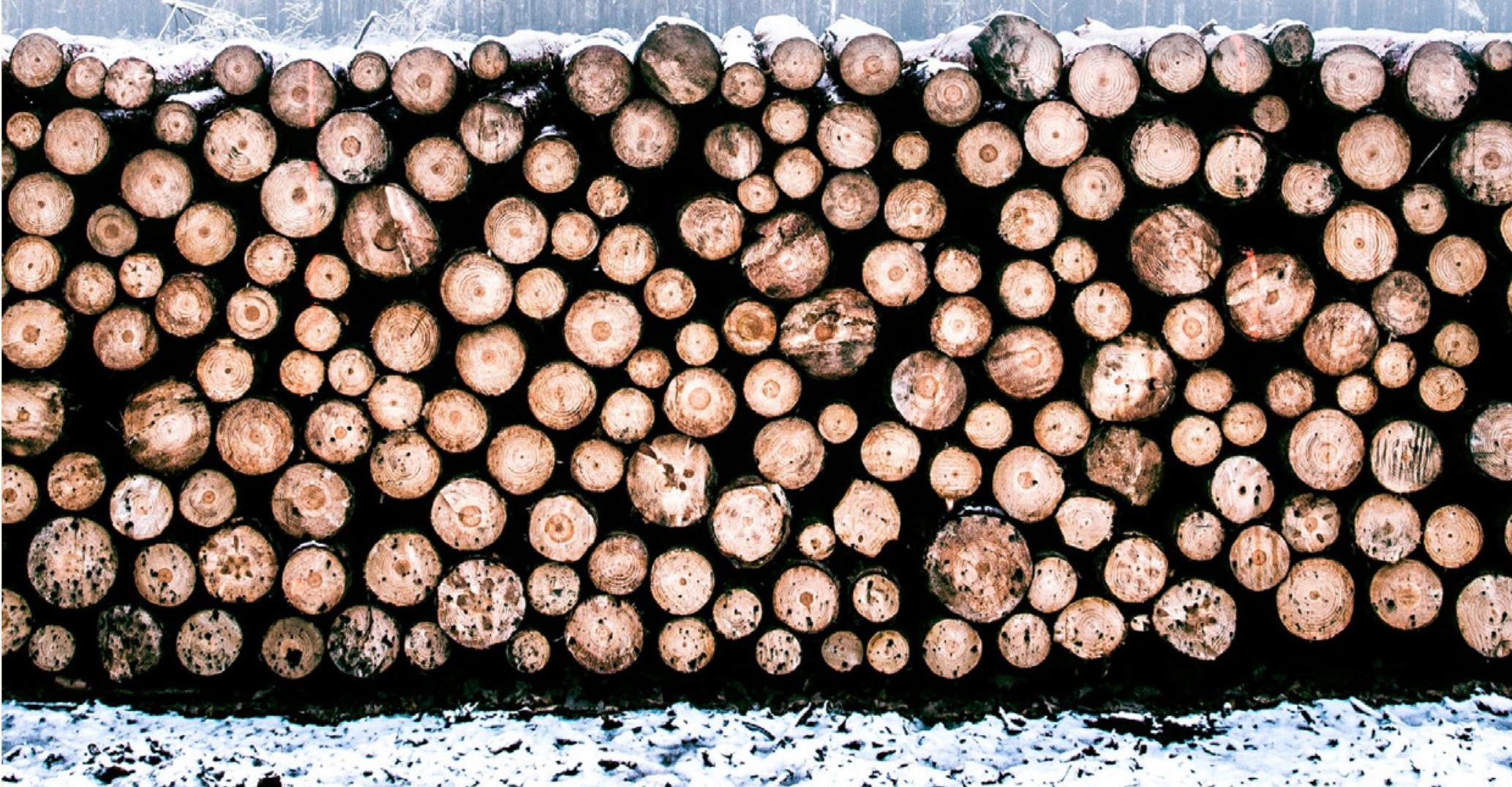





\section{Potentials for reducing the health and climate impacts of residential biomass combustion in the Nordic countries}

Karin Kindbom, Tomas Gustafsson, Stefan Åström, Ole-Kenneth Nielsen and Kristina Saarinen 
Potentials for reducing the health and climate impacts of residential biomass combustion in the Nordic countries Karin Kindbom, Tomas Gustafsson, Stefan Åström, Ole-Kenneth Nielsen and Kristina Saarinen

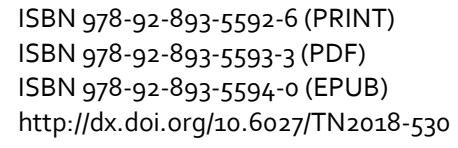

TemaNord 2018:530

ISSN 0.908-6692

Standard: PDF/UA-1

ISO 14289-1

(c) Nordic Council of Ministers 2018

Cover photo: Unsplash.com

Print: Rosendahls

Printed in Denmark

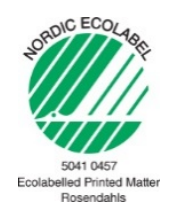

\section{Disclaimer}

This publication was funded by the Nordic Council of Ministers. However, the content does not necessarily reflect the Nordic Council of Ministers' views, opinions, attitudes or recommendations.

\section{Rights and permissions}

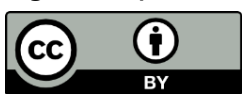

This work is made available under the Creative Commons Attribution 4.0 International license (CC BY 4.0) https://creativecommons.org/licenses/by/4.0

Translations: If you translate this work, please include the following disclaimer: This translation was not produced by the Nordic Council of Ministers and should not be construed as official. The Nordic Council of Ministers cannot be held responsible for the translation or any errors in it.

Adaptations: If you adapt this work, please include the following disclaimer along with the attribution: This is an adaptation of an original work by the Nordic Council of Ministers. Responsibility for the views and opinions expressed in the adaptation rests solely with its author(s). The views and opinions in this adaptation have not been approved by the Nordic Council of Ministers. 
Third-party content: The Nordic Council of Ministers does not necessarily own every single part of this work. The Nordic Council of Ministers cannot, therefore, guarantee that the reuse of third-party content does not infringe the copyright of the third party. If you wish to reuse any third-party content, you bear the risks associated with any such rights violations. You are responsible for determining whether there is a need to obtain permission for the use of third-party content, and if so, for obtaining the relevant permission from the copyright holder. Examples of third-party content may include, but are not limited to, tables, figures or images.

Photo rights (further permission required for reuse):

Any queries regarding rights and licences should be addressed to:

Nordic Council of Ministers/Publication Unit

Ved Stranden 18

DK-1061 Copenhagen K

Denmark

Phone +4533960200

pub@norden.org

\section{Nordic co-operation}

Nordic co-operation is one of the world's most extensive forms of regional collaboration, involving Denmark, Finland, Iceland, Norway, Sweden, and the Faroe Islands, Greenland and Åland.

Nordic co-operation has firm traditions in politics, economics and culture and plays an important role in European and international forums. The Nordic community strives for a strong Nordic Region in a strong Europe.

Nordic co-operation promotes regional interests and values in a global world. The values shared by the Nordic countries help make the region one of the most innovative and competitive in the world.

The Nordic Council of Ministers

Nordens Hus

Ved Stranden 18

DK-1061 Copenhagen K, Denmark

Tel.: +4533960200 www.norden.org

Download Nordic publications at www.norden.org/nordpub 



\section{Contents}

Summary .7

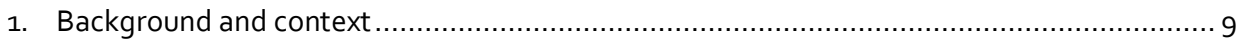

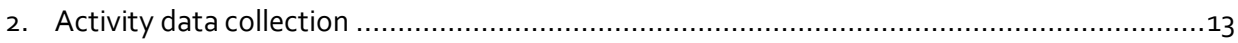

2.1 Current national activity data collection procedures ........................................13

2.2 Recommendations on future improvements................................................ 20

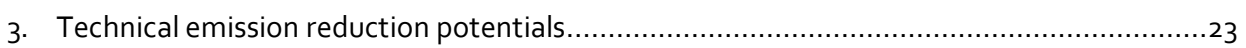

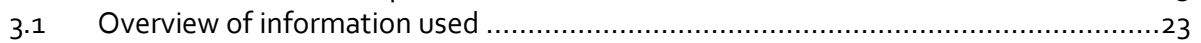

3.2 National activity data baseline projections (WEM) ....................................... 24

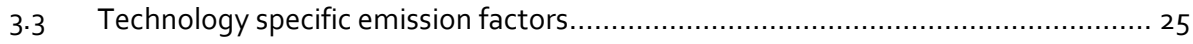

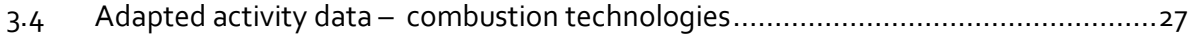

3.5 Calculation of health impact......................................................................... 29

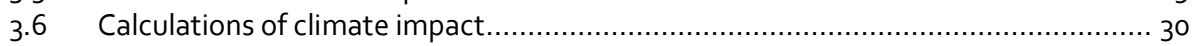

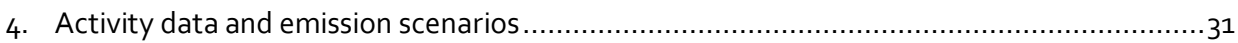

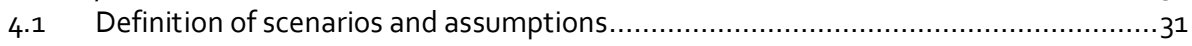

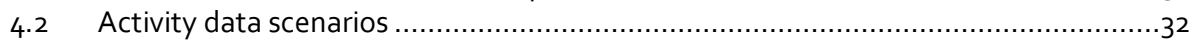

4.3 Brief comparison of national emissions (WEM) and expected scenario (SC1) ...........33

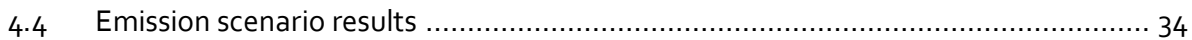

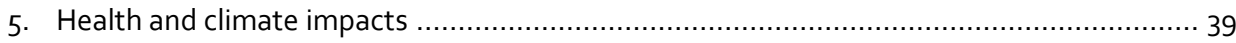

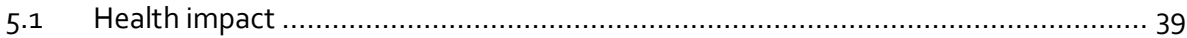

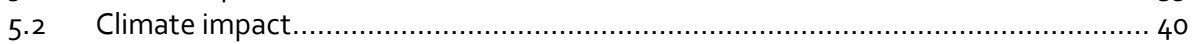

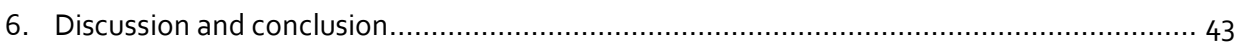

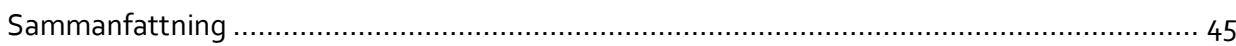

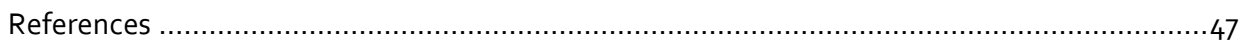





\section{Summary}

Residential biomass combustion is a major source of PM2.5 and SLCP (Short Lived Climate Pollutants) emissions in the Nordic countries. SLCPs and PM2.5 have impact on climate, environment and health. To develop strategies for reducing emissions and the associated impacts, reliable information on current emissions and how they can be reduced by measures such as upgrading or exchange of combustion technologies is essential.

This report presents recommendations for how to further improve national activity data collection procedures, and scenario results with estimated technical potentials for reduced emissions of SLCPs and PM2.5 from residential biomass combustion, transformed into potential impact on health and climate effects in 2035.

The project was financed by the Nordic Council of Ministers' Climate and Air Pollution Group and complements the larger Nordic project "Improved emission inventories of Short Lived Climate Pollutants (SLCP)" (Kindbom et al. 2015, Kindbom et al. 2017) financed by the Nordic Council of Ministers.

There are uncertainties in the underlying data used in the emission inventories for residential biomass combustion. Detailed enough knowledge on the amount and moisture content of biomass fuel used in different combustion technologies is needed, as well as knowledge about user related factors such as combustion behaviour.

There are similarities between Denmark, Finland and Sweden, but also some significant differences in national equipment and use patterns in addition to activity data collection procedures. Differences related to information on activity data are mainly in the status of knowledge and the type and sources of information available and/or used. In general for all three countries, procedures to regularly update information on technologies, user behaviour and fuel amounts combusted in each technology are needed to be able to prepare reliable emission inventories and to reflect future changes. As the current data collection procedures in the countries have evolved somewhat differently, but all with the same ultimate objective of good enough data for emission inventory purposes, lessons can be learnt from each other, as appropriate.

The scenario results suggest that there is a realistic and technical potential to reduce the adverse health effects and, to some extent, the climate impact from future residential biomass combustion in Denmark, Finland and Sweden by reducing emissions of SLCPs and PM2.5. The level of used amounts of wood, penetration of modern technology in residential biomass combustion and the user behaviour in managing the combustion process all have significant impacts on the emission levels in the three Nordic countries. The amount of biomass fuel combusted was not investigated in this study and the total amount of biomass was kept constant in all scenarios. The results in this study show that: 
- the estimated potential reduction of PM2.5 emissions would lead to significant reductions in adverse health effects. In the order of 1000 premature deaths would be avoided annually in Europe in 2035 as a result of replacing older boilers and stoves with modern equipment and good combustion behaviour;

- the reduced climate impact resulting from reduced emissions of the short lived climate pollutants $\mathrm{BC}, \mathrm{CH}_{4}$, NMVOC and $\mathrm{OC}$ from residential biomass burning is rather modest and more of a positive side effect in addition to the reduced health effects from reducing PM2.5 emissions. The potential emission reductions estimated in the scenarios correspond to approximately $0.1 \%$ of the projected greenhouse gas emissions from Denmark, Finland and Sweden in 2030;

- according to current national projections the use of older technology stoves and boilers in Denmark, Finland and Sweden are expected to only account for about $7 \%$ (10 PJ of $148 \mathrm{PJ}$ ) of total residential biomass use in 2035 . The results show that the potential to reduce emissions from residential biomass burning by replacing those older technologies with modern equipment by 2035 can be significant, in the order of $15 \%$ for $\mathrm{PM}_{2} .5$ and $\mathrm{OC}, 25 \%$ for $\mathrm{NMVOC}$ and $7-9 \%$ for $\mathrm{BC}$ and $\mathrm{CH}_{4}$;

- if, in addition to replacement of older equipment, the combustion behaviour is improved from the assumed $90 \%$ up to $100 \%$ of the population having good combustion behaviour, the potential to reduce the emissions rises to $26 \%$ for $\mathrm{PM} 2.5,32 \%$ for OC, $35 \%$ for NMVOC, $15 \%$ for $\mathrm{CH}_{4}$ and $8 \%$ for $\mathrm{BC}$;

- there are incentives to introduce policies for early scrapping of old devices and replacement to modern equipment. Effective information campaigns to educate users in proper combustion behaviour are also important, since a successful change in combustion behaviour can have a large effect on emissions.

Alternative developments, especially in the amount of biomass fuel used, would have a large effect on resulting emissions. Additional alternative developments, such as different rates of replacement of old with modern equipment, or technological development towards even lower-emitting combustion equipment would also affect the results.

In this study the emission factors developed in the measurement programme (TN2017:570) carried out as part of the Nordic SLCP project were used. The national combustion technology splits for residential biomass combustion used in the national inventories in Denmark, Finland and Sweden were adapted into the split of technology types for which the measurements in the Nordic project were carried out. The results of this study are complementary to the national projections and emission inventories and are not necessarily consistent with them. 


\section{Background and context}

Residential biomass combustion is a major source of PM2.5 and SLCP (Short Lived Climate Pollutants) emissions in the Nordic countries. SLCPs and PM2.5 have impact on climate, environment and health. To develop strategies for reducing emissions and the associated impacts, reliable information on current emissions and how they can be reduced by measures such as upgrading or exchange of combustion technologies, as well as by improved user behaviour are essential.

This project consisted of two main tasks:

1. Provide recommendations for collection of activity data suitable for the technology specific emission factors developed in the project "Improved Nordic emission inventories of SLCP", financed by the Nordic Council of Ministers.

2. Present estimates on technical potentials for reduced emissions of SLCPs (and PM2.5) from residential biomass combustion, transformed into potential impact on health and climate effects.

National emission inventories of greenhouse gases and air pollutants are annually reported to international conventions (e.g. the UNFCCC and the CLRTAP). Emission estimates are based on activity data on biomass consumption and emission factors from EMEP/EEA Emission Inventory Guidebook or on national emission factors. For many countries, due to difficulties in obtaining data on the use of biomass fuels and the challenges in deriving national emission factors, the current emission estimates are highly uncertain. This applies especially to particular matter (PM2.5, BC(EC)).

In the first report from the Nordic SLCP-project "Improved Nordic emission inventories of SLCP" (TN2015:523), emission estimates for residential biomass combustion and the underlying data were analysed. It was identified that actual differences exist in combustion technologies, combustion practices and user behaviour between the countries. The current calculation methods in the countries reflect the availability or lack of data. The comparability of emission factors presently used in the national inventories is also impacted by the fact that they are derived from measurement results which are based on different measurement standards, e.g. using either diluted or non-diluted samples.

The Nordic SLCP-project also included an extensive measurement program to develop comparable and harmonised technology specific emission factors for PM2.5, $B C, O C, E C, \mathrm{CH}_{4}$ and NMVOC from residential biomass combustion. The results are presented in a separate report, $\mathrm{TN}$ 2017:570. Several combustion technologies common in the Nordic countries were covered. Based on the results, the actual emissions vary widely between the different types of residential biomass combustion technologies and user practices. The results show, for example, that older manually fed boilers without 
accumulator tank used under bad firing conditions, such as using moist fuel, incorrect air flow and part fuel load, yield the highest emission factors for most air pollutants (TN2017:570). These results are similar to previous studies (e.g. Todorovic, 2007 and UEF, 2011).

In order to make full use of the technology specific emission factors developed in the Nordic SLCP project (TN2017:570) it is essential to be able to allocate the biomass use to the technologies and operating conditions that the emission factors represent. Thus collection of national data on technologies and the amount and type of fuel used in these technologies is needed. Technology specific emission factors and technology specific activity data will improve the emission estimates in those Nordic countries where these data have not previously been available, and thus also the national assessments, emission inventories for international reporting, and the basis for emission reduction strategies. Improved quality and completeness of activity data (i.e. combustion technology stock and technology specific fuel consumption) was not covered in the Nordic SLCP-project.

In Table 1 factors influencing uncertainties in emission estimates from residential biomass combustion are presented (TN2015:523). Factor number 1, "Emission measurement method" was addressed for the appliances tested in the measurement program (TN2017:570). Factors 2 "Operation and handling" and 5 "Fuel quality", were partly addressed as the measurement program included testing at non-optimal combustion conditions and also using moist fuel. Factors 3 and 4 , activity data on fuel consumption and combustion technologies, were not covered within that project, and are therefore considered in this present project (task 1).

This report contains a short description of the current situation in Sweden, Denmark and Finland regarding the collection of activity data for estimating emissions from residential biomass combustion. It also provides recommendations on ways to improve the data collection in order to facilitate the use of technology-specific emission factors. The ultimate objective of improved data collection procedures is to reduce uncertainties and to improve comparability between national emission inventories for residential biomass combustion.

There are several international initiatives aimed at reducing emissions of SLCP, and especially of Black Carbon, BC (e.g. Arctic Council EGBCM, CCAC, and the Gothenburg Protocol under UNECE CLRTAP). Furthermore, recent agreements under the EU Ecodesign Directive aim at reducing emissions from solid fuel boilers and room heaters. Since residential biomass combustion contributes significant shares of national emissions, estimates of the technical emission reduction potentials are highly relevant information to take into consideration when developing emission reduction strategies.

In this project, under task 2, the technical potential for reduced climate impact and reduced health effects from residential biomass combustion are estimated. The technology specific emission factors for $\mathrm{PM}_{2} .5, \mathrm{OC}, \mathrm{EC}, \mathrm{CH}_{4}$ and NMVOC developed in the Nordic SLCP project, and activity data defined in task 1 in this project are used in combination with possible scenarios for future residential biomass combustion technology development. 
Table 1: Factors affecting emission estimates from residential wood combustion (TN2015:523)

\begin{tabular}{|c|c|c|c|}
\hline Factor & Why/how? & Judged importance & $\begin{array}{l}\text { Possible/feasible to } \\
\text { improve? }\end{array}$ \\
\hline $\begin{array}{l}\text { 1. Emission measurement } \\
\text { method for deriving emission } \\
\text { factors }\end{array}$ & $\begin{array}{l}\text { Sampling methods, sample } \\
\text { treatment and analysis differ } \\
\text { in different measurement } \\
\text { standards. For instance, hot } \\
\text { flue gas/diluted flue gas } \\
\text { measurements give different } \\
\text { results. }\end{array}$ & Important & $\begin{array}{l}\text { Information on sampling } \\
\text { and measurement methods } \\
\text { and data processing used } \\
\text { for deriving the emission } \\
\text { factor needs to be } \\
\text { documented to understand } \\
\text { how to use the EFs. }\end{array}$ \\
\hline $\begin{array}{l}\text { 2. Operation and handling of } \\
\text { combustion }\end{array}$ & $\begin{array}{l}\text { Firing practices and habits, } \\
\text { e.g, firing with restricted air } \\
\text { supply results in incomplete } \\
\text { combustion and higher } \\
\text { emissions. Also the use of } \\
\text { moist fuel is a factor on the } \\
\text { responsibility of the user but } \\
\text { listed here under point } 4 \text {. } \\
\text { Activity data. Different } \\
\text { factors impact different } \\
\text { combustion equipment at } \\
\text { different rates and may differ } \\
\text { between countries. }\end{array}$ & $\begin{array}{l}\text { Important, especially for } \\
\text { most manually fed devices. }\end{array}$ & $\begin{array}{l}\text { Should be taken into } \\
\text { account in the country } \\
\text { specific EFs based on } \\
\text { assumptions/knowledge of } \\
\text { common practices }\end{array}$ \\
\hline $\begin{array}{l}\text { 3. Activity data (fuel } \\
\text { consumption) }\end{array}$ & $\begin{array}{l}\text { There is an inherent } \\
\text { uncertainty in the activity } \\
\text { data for residential wood } \\
\text { combustion. Solid data } \\
\text { requires detailed } \\
\text { representative surveys } \\
\text { potentially coupled with } \\
\text { energy demand modelling. }\end{array}$ & Critical & $\begin{array}{l}\text { Not addressed within the } \\
\text { Nordic SLCP project. } \\
\text { Improved accuracy could be } \\
\text { achieved through (detailed } \\
\text { enough) data collection, } \\
\text { e.g. use of wood in different } \\
\text { equipment }\end{array}$ \\
\hline $\begin{array}{l}\text { 4. Activity data (combustion } \\
\text { technology) }\end{array}$ & $\begin{array}{l}\text { Data on the split of the } \\
\text { overall wood consumption } \\
\text { between the different } \\
\text { technologies can be collected } \\
\text { by detailed studies/surveys } \\
\text { within each country. In } \\
\text { addition to the split of wood } \\
\text { use in the different } \\
\text { technologies, also the } \\
\text { characteristics of the } \\
\text { technologies themselves may } \\
\text { differ between the countries. }\end{array}$ & $\begin{array}{l}\text { Critical } \\
\text { Increases accuracy when } \\
\text { taken into account, as } \\
\text { emission factors vary } \\
\text { between technologies }\end{array}$ & $\begin{array}{l}\text { Not addressed within the } \\
\text { on-going Nordic SLCP } \\
\text { project. } \\
\text { Surveys to households, by } \\
\text { chimney sweepers, sales } \\
\text { statistics, expert estimates }\end{array}$ \\
\hline 5. Activity data (fuel quality) & $\begin{array}{l}\text { A few studies have } \\
\text { investigated the importance } \\
\text { of e.g. wood type, moisture } \\
\text { chemical content, etc., } \\
\text { however, many of these } \\
\text { aspects are still poorly } \\
\text { understood. The moisture of } \\
\text { wood has an important } \\
\text { impact on emissions and is } \\
\text { largely impacted by the user. }\end{array}$ & $\begin{array}{l}\text { Important } \\
\text { If possible, should be taken } \\
\text { into account in the EF, by } \\
\text { expert assumptions }\end{array}$ & $\begin{array}{l}\text { Surveys to chimney } \\
\text { sweepers, expert } \\
\text { assumptions }\end{array}$ \\
\hline
\end{tabular}





\section{Activity data collection}

Emissions from residential biomass combustion are calculated by multiplying activity data $(A D)$ with technology specific emission factors (EF) according to the following equation:

- Emissions=AD (MJ fuel used)*EF (mg/MJ).

The activity data (AD) consist of the type and amount of biomass fuel used in a specific technology. The emission factor represents the amount of pollutant emitted per energy unit of fuel combusted (e.g. mg/MJ).

As a background for recommendations on improved activity data collection procedures, the current practices of activity data collection for residential biomass combustion in Denmark, Finland and Sweden are presented below.

In the Nordic countries the number of different residential combustion technology categories included in the emission inventory ranges from 6 nationally defined categories in Sweden, to 10 in Denmark and 13 in Finland (TN2015:523). A general overview of the national processes for activity data collection is available in ACAP (2014). One of the key findings in that study is that that the different technology categories used in emission inventory work make direct comparisons between countries challenging (chapter 5.8, ACAP, 2014).

\subsection{Current national activity data collection procedures}

\subsubsection{Denmark}

Every other year there is a survey conducted. They survey is co-financed by the Danish EPA and the Danish Energy Agency. Previously, the survey was conducted as phone interviews and the latest one consisted of approximately 2100 households. Of these 2,100 only about 600 actually have a wood burning appliance and hence it is quite a small sample. The wood consumption is then estimated by considering the total number of households in Denmark and the estimated consumption per appliance based on the survey. The latest survey in 2016 used a web-based approach and therefore managed to get a lot more respondents. In total, the survey was conducted on 13,229 households of which 4,506 had a wood burning appliance. 
In the survey there are many additional questions, of which the most interesting from an emission inventory standpoint is the information on the age of the appliance, e.g. for stoves whether they are from before 1990, between 1990 and 2005 and after 2005. The latest version was published in late $2016 .^{1}$

Of course the survey when conducted every other year will give different results and an unfair picture of the actual development, but where the changes are within the uncertainties. Therefore, the specific data for age distribution and number of appliances are used and updated every two years. A constant number of 750,000 stoves and about 45,000 boilers is used so far. For the age distribution, results from a study in 2006 are used and the annual replacement rates have been estimated thereafter. The Danish regulation of room heaters and boilers, since 2008 , is assumed to cut certain old appliances from the market, and the penetration rate of new appliances into the stock is determined by the renewal rate of each appliance type.

In 2017, data on the type and placement of nearly all appliances were made available from the Danish Chimney Sweepers Association (Skorstensfejerlauget). This data will be implemented in the future, as it is believed to be the most authoritative dataset on the number of specific appliances. Unfortunately, the first data collection did not contain information on the age of the appliance, but there is a possibility that this could be included in future data collection.

Denmark plans to use heat demand modelling, but this would only be for verification purposes. Information on the use of wood pellets is collected through a statistical survey carried out by the Danish Energy Agency. ${ }^{2}$ For projections, the energy consumption is calculated based on modelling carried out by the Danish Energy Agency. The latest report is available in Danish. ${ }^{3}$

\subsubsection{Finland}

\section{Methodology}

A national methodology is used to estimate emissions from residential combustion. The calculation includes information on:

- Activity sector and house types where the wood is combusted.

- Shares of wood types (firewood, wood chips and pellets) combusted in the different equipment in the different sectors and house types.

- Emission factors derived from equipment specific measurements for 13 technology categories for good, normal and bad combustion conditions, which differ between equipment and pollutant:

\footnotetext{
${ }^{1}$ https://ens.dk/sites/ens.dk/files/Statistik/braende_2015.pdf (In Danish)

${ }_{2}^{2}$ Information on the methodology is available at https://ens.dk/sites/ens.dk/files/Statistik/metode_traepiller-2010.pdf) and information on the latest survey report (in Danish) at

(https://ens.dk/sites/ens.dk/files/Statistik/det_danske_traepillemarked_2014.pdf

3 https://ens.dk/sites/ens.dk/files/Basisfremskrivning/baggrundsrapport_til_bf_2017.pdf
} 
- Automatic Fed Wood Chips.

- Automatic Fed Pellets.

- Manually Fed with accumulator.

- Manually Fed without accumulator.

- Manually Fed Modern.

- Open fire place and other stoves.

- Kitchen range.

- Masonry Heaters Conventional.

- Masonry Heaters Modern.

- Masonry Ovens.

- Sauna stoves.

- Iron stoves conventional.

- Iron stoves modern.

The development of technology over time is taken into account through changes of wood combusted in the different equipment.

User influence is taken into account through the shares of normal and bad combustion of the total wood combusted in each equipment type (see footnote in Table 4) (Savolahti et al., 2014).

\section{Collection of wood use data}

Finnish Forest Research Institute Metla and Statistics Finland collect wood use data through a survey to real estates on the energy sources of the heating systems. Information on wood used for heating and other purposes in all buildings on the real estates is reported in cubic metres by wood species (i.e. logs 0.6-1.2 meter, chopped wood $0.2-0,6$ meter or chips), sawing rests, laths, surfaces, construction rests and recycled wood, sawdust/sawchips, bark, pellets, briquettes and in the category "other"). The origin of wood from forest and recycled/byproduct/wastewood is reported as from own forest, received or bought from elsewhere.

The use of wood in the different buildings is reported for the main building (without sauna), other residential buildings (without sauna), sauna, agricultural production buildings and outhouses, and other use.

The use of wood in the different equipment is reported for sauna stoves and pots, heat storing heaters and stoves, baking ovens and combination ovens, kitchen ranges, wood stoves, light stoves, convection ovens/stoves, stove hearts, iron stoves, fireplaces, open fires (bonfires, yard kitchens) as well as for central heating boilers (chopped wood boilers with or without accumulator, chip and pellet boilers). The number and year of acquisition of heat storing heaters is also included in the questionnaire.

The frequency of the survey aims at every five years and is decided on project basis. For the intermediate years the results of the previous questionnaire are scaled according to the degree days. 
The results of the survey are included in the inventory in addition to expert judgement and other information from studies that have been carried out over several decades such as interviews with chimney sweepers and local surveys and sales statistics. Information on heating equipment registered in the building licences are not yet utilized in the inventory.

Activity data used in the projections (Savolahti et al. 2015 and 2016)

Emission projections are prepared using fuel by technology. Only the impacts of the ecodesign directives are taken into account in the baseline scenario assuming that modern appliances become more popular due to market mechanisms or the eco-design directive.

The average lifetime of different appliances is taken into account when estimating changes in the stock. The Ecodesign directive is assumed to cut certain old appliances from the market, and the penetration rate of new appliances into the stock is determined by the renewal rate of each appliance type. Sauna stoves are not included in the Ecodesign directive. Modern masonry heaters are the only "modern" appliances that are assumed to be sold in meaningful numbers already without eco-design. The data for room heaters in 2030 is estimated based on the changes in the amount of detached houses and the prevalence of stoves in newly built houses, and the data for boilers is based on historical trends. Based on sales statistics, the only technologies that already play a significant role in the market, i.e. modern masonry heaters and pellet boilers, can become considerably more common by 2030 .

The emission factors stay the same, although the overall emission factors decrease due to the impact of the eco-design directives, and the user behaviour is kept the same over time.

Lifetimes of Finnish equipment used in the emission scenarios are (Savolahti et al., 2016):

- Manually stoked modern boiler 30

- Accumulator tank to a manually stoked boiler 30

- Conventional masonry heater 35

- Modern masonry heater 35

- Wood stove 12.5

- Modern wood stove 20

- Sauna stove 12.5

- Modern sauna stove 20

\subsubsection{Sweden}

The main data source for fuel use is the annual energy balances, produced by the Swedish Energy Agency. Statistics on residential biomass consumption is based on several stratified sample surveys covering one- and two-dwelling buildings, multi-dwelling buildings and holiday cottages. Surveys for one- and two-dwelling and multi-dwelling buildings are carried out annually or biannually to about 7,000 owners, respectively. Biomass consumption in holiday cottages have been surveyed 1976, 2001 and 2012. 
Fuel consumption for heating residences is surveyed on three types of biomass: wood logs, pellets/briquettes and wood chips/saw dust. In addition, respondents are asked about the type of combustion technologies: wood log boilers, other biomass boilers, and stoves/open fire places. However, the annual surveys do not allow for matching of the type of biomass to the type of combustion technology in cases where biomass is used in different technologies. E.g. wood logs used in boilers and stoves are reported together. In 2003 and 2010, extended sample surveys to about 100,000 oneand two-dwelling buildings were carried out, allowing for more elaborated analyses on biomass consumption by type of combustion technology. In the national emission inventory information from the 2003 and 2010 surveys have been extrapolated to cover the time series 1990-2015.

Information on the age (split in three categories) of the biomass heating appliances has only been included in the survey questionnaire for one- and two-dwelling buildings since 2014. The survey for one- and two-dwelling buildings also includes information on if a biomass heating appliances is equipped with accumulator tank. The available information on age split or on the presence of accumulator tanks has not yet been used in the national emission inventory.

Table 2 below shows the representation $(X)$ of different biomass fuels by heating technology in Sweden. National emission factors for the technologies and fuels are based on a national study from 2006 (Paulrud et al. 2006).

Table 2: Biomass fuels by heating technology in Sweden

\begin{tabular}{lccc} 
Biomass type & & Heating technology & \\
& Boiler & Stove & Open fire place \\
Wood logs & $\mathrm{X}$ & $\mathrm{X}$ & $\mathrm{X}$ \\
Pellets/briquettes & $\mathrm{X}$ & $\mathrm{X}$ & \\
Wood chips/saw dust & $\mathrm{X}$ & & \\
\hline
\end{tabular}

Projections of future total biomass fuels used for residential heating in Sweden are developed by the Swedish Energy Agency (Energimyndigheten, 2017) (Table 3). The projections do not account for possible changes between different types of biomass or combustion technologies over time. Hence, all fuel types (wood logs, pellets, wood chips) are assumed to have the same projected relative increase. The projection data is the base for the emission projections reported to the EU, UNFCCC and CLRTAP.

Table 3 Projections of future total use of biomass in Sweden, percentage change from 2014 to years 2020-2035, respectively

\begin{tabular}{|c|c|c|c|c|}
\hline Projected change & $2014-2020$ & $2014-2025$ & $2014-2030$ & $2014-2035$ \\
\hline Residential biomass use & $+15 \%$ & $+14 \%$ & $+9 \%$ & $+10 \%$ \\
\hline
\end{tabular}




\subsubsection{Summary of AD collection processes}

The collection of data at the level of detail needed for emission inventories is resource demanding. Desired information often needs to be compiled and combined from a number of different sources. In Table 4 current activity data collection processes in Sweden, Finland and Denmark are presented. In summary, the national data collection procedures include information from research, other studies, surveys, national statistics, sales figures from different manufacturers, chimney sweepers, as well as expert assumptions. There are similarities, but also differences in the data sources used and/or available between the countries. In addition to differences in data collection, it should also be noted that contrary to what might be expected for the three Nordic countries, residential combustion activities are not the same in the countries due to different technologies and user practices

The equipment in which wood is combusted has a large impact on the resulting emissions. Therefore information on the existing combustion technologies is critical, as is information on the shares of wood combusted at least in the main types of the different combustion technologies. Information on user influenced factors (e.g. combustion behaviour to determine share of bad combustion) can be collected from chimney sweepers who have a general insight based on their experience.

Both in Finland and Sweden, the share of bad firing habits has been estimated to be around $10 \%$. Information on storage of wood, which impacts wood moisture, is not covered by data collection in any of the Nordic countries. Based on the impact of moist wood to emissions, more accurate information on wood storage and the actual moisture of wood combusted would be needed. 
Table 4. Summary of current AD collection processes in Sweden, Denmark and Finland

Factor Sweden Finland Denmark

Operation and handling (User influence)

Activity data
(fuel
consumption)

For $\mathrm{CH}_{4}, 10 \%$ are assumed to have "bad firing habits". No assumptions on boilers with accumulation tank

Currently via annual postal energy surveys by the Swedish Energy Agency. $58 \%$ response rate. About $33 \%$ of al small scale households (one-and two-dwelling buildings) use biomass.

Activity data (combustion technology)

Activity data (fuel quality)
Energy Agency's survey: wood logs, pellets/briquettes, chips; by boiler, stove, open fire place.

No information on age or implementation of advanced combustion technologies available so far.

There is no information or assumptions made on fue quality. In Sweden, a mix of birch and spruce wood logs are most common, but there is a large variation.
The $10.5 \%$ share of smouldering combustion is used for all inventory and projection years assuming that no smouldering combustion occurs with good users ( $55 \%$ of all), $10 \%$ occurs with decent users (30\% of all) and $50 \%$ occurs with poor users (15\% of all) 4

Survey to real estates by Finnish Forest Research Institute Metla and Statistics Finland. Wood is a primary heating method in $25 \%$ of residential and most recreational buildings and secondary in almost all residential and recreational houses- There are about 2.5 million small scale wood burning devices in addition to 1.5 million sauna stoves.

Technology and installation year in the questionnaire presented above, in addition, registration of heating device in building licences includes the year installed. Some studies also cover this. Life times: manual modern/with accumulator boiler 30 a, masonry ovens min 35 a, modern wood/sauna stove $20 \mathrm{a}$, conventional wood/sauna stove 13 $a^{5}$

Combustion of moist wood is taken into account through the "bad combustion" share of wood combusted in the inventory, see above. Emissions from different tree species is available in the PUPO $^{6}$ database (differences in emissions low) and use of different wood species is not systematically collected and not included in the inventory. Information on wood types (logs, chops, chips, sawing/construction rest, laths, surfaces, recycled wood, sawdust/sawchips, bark, pellets, briquettes and Other) is collected for other purposes but not used in the inventory.
No assumptions are made regarding user behaviour. The default EFs from the EMEP/EEA Guidebook are assumed to be a representative average.

Survey carried out biennially. Latest survey was a web-based survey covering the number of appliances, the age of appliances, the wood consumption per appliance type and several other issues.

Information is included in the biennial survey. So far a study from 2006 has been used. The model will be updated in 2018

There are no assumptions made regarding fuel quality. The default EFs from the EMEP/EEA Guidebook are assumed to be a representative average

4 The share of users in each of the three user profiles is based on two sets of questionnaires for chimney sweeps: one in southern Finland and one in the whole of Finland. The share of smouldering combustion takes into account typical user mistakes, such as suboptimal batch sizes and ignition, insufficient air supply and poor quality of fuel (wet wood or waste). The impact of an informational campaign that educates heater users on

proper combustion habits was also estimated in a sensitivity study, where the range of efficiency for the campaign was from $5 \%$ to $50 \%$ reduction in total share of smouldering combustion. The assumed best case scenario would mean that roughly $60 \%$ of both decent and poor heater users had improved their habits and were moved to the profile above them. (Savolahti M. et al., 2016)

5 Savolahti et al. 2016 and information from manufacturers 


\subsection{Recommendations on future improvements}

The purpose of this project was to support collection of detailed enough activity data suitable for technology (and user practice) specific emission factors, and to apply the results from the measurement program in the Nordic SLCP project (TN2017:570), where applicable. In order to be useful for future national emission inventories, wood consumption data collection procedures need to be able to capture changes over time, in technology stock and in user behaviour/combustion practices.

The current activity data collection procedures are different in some aspects between Denmark, Finland and Sweden. For example, there is already a detailed disaggregation on technologies in Denmark and Finland. Information on the firing habits has already been collected to some extent, but possible changes in the future need continuous follow-up in all countries.

Below, some recommended improvements in activity data collection in the individual countries are listed.

\subsubsection{Denmark}

The expansion of the data collection from the chimney sweepers is planned to include data on the age of the appliance as well as a qualitative evaluation of the extent of use of the appliance, which would greatly improve the accuracy.

The survey could then focus more on the unit consumption for different types of appliances and also depending of the building use, e.g. establishing with more certainty unit consumption rates for a wood stove depending on whether it is in a house, an apartment building or a summer cottage.

\subsubsection{Finland}

Finland already has a system in place to collect wood use data and to allocate this into the nationally developed split of technologies. Finland also already uses a method to estimate the impact of user behaviour on emissions, based on the shares of good/bad combustion conditions for each technology and pollutant (Savolahti et al. 2014). Further work is expected for the definition of modern sauna stoves and related emission factors. Information on the storage conditions of wood should be better studied to have more accurate information of the moisture content of wood combusted. In addition, information on the development of firing habits should be updated regularly, e.g. every 5-10 years to reflect impacts of education campaigns in the inventory. The wood use survey should be made at regular intervals.

${ }^{6}$ www.uef.fi 


\subsubsection{Sweden}

The collection of activity data on residential biomass combustion should be improved on the following aspects:

- More detailed collection of different types of combustion technologies together with biomass consumption specified by type of biomass.

- Heating appliances connected to an accumulator tank.

- Age of appliance.

- Share of users with bad firing habits.

In Sweden, there are several ways that could contribute to improve the collection of activity data on residential biomass consumption:

- Make more use of the existing energy consumption survey to households by the Swedish Energy Agency by taking into account information on accumulator tanks and age of appliance.

- Extend the existing energy consumption survey to households by the Swedish Energy Agency to include more specific questions on the use of biomass and heating appliances.

- Develop a specific survey to households using biomass, including more detailed information on type of biomass used and type of combustion technologies. In Gustafsson and Helbig (2017) the results from a Swedish pilot study indicate that households to a large degree are able to give sufficient responses to such questions.

- Develop a feedback mechanism for chimney sweepers that include information on combustion technologies, and if possible, indication on combustion habits/conditions. The information could be collected via existing reporting of fire safety to the Swedish Civil Contingencies Agency (MSB). It could also be collected via specific surveys directly to the chimney sweepers. The latter was carried out in the Swedish pilot study by Gustafsson and Helbig (2017). 



\section{Technical emission reduction potentials}

In order to estimate technical emission reduction potentials from residential biomass combustion, scenarios on future technology stock composition changes in the countries were defined. These scenarios provide estimates of how emissions will change if currently used technologies are exchanged for modern/low-emitting technologies. Also the impact of improved user practices was assessed.

Scenarios for future emissions were based on realistic assumptions of changes in technology stock, where the current technology stock was adapted to match the technology specific emission factors from the Nordic SLCP project (TN2017:570). The technology scenarios were combined with three different levels of assumed degree of bad combustion behaviour. The differences in estimated emissions between the current status and the scenarios were estimated by applying technology and behaviour specific emission factors for PM2.5, EC/BC, OC, CH4 and NMVOC (TN2017:570).

The estimated potentials for reduced emissions of SLCPs (and PM2.5) from residential biomass combustion were transformed into potential impact on health and climate.

\subsection{Overview of information used}

- National activity data baseline (technologies and fuel use) with historic data 2005-2015, and national projections to 2030 or 2035 (from official national reporting). Projections represent conditions "with existing measures", WEM. Described in chapter 3.2.

- Technology and behaviour specific emission factors developed in the Nordic SLCP-project (TN2017:570). Described in chapter 3.3).

- Adaptation of national baseline activity data (combustion technologies) to be aligned with emission factors. Developed in this project. Described in chapter 3.4.

- Method used to calculate the health impact, GAINS and Alpha-RiskPoll models. Described in chapter 3.5.

- Climate calculations and metrics used to calculate climate impact (IPCC 2013). Described in chapter 3.6. 


\subsection{National activity data baseline projections (WEM)}

Total biomass fuel consumption in residential biomass combustion ( $\left.1 \mathrm{~A}_{4} \mathrm{bi}^{7}\right)$ was in 2015 about $37 \mathrm{PJ}$ in Denmark, $50 \mathrm{PJ}$ in Finland and $42 \mathrm{PJ}$ in Sweden. The projected fuel use is a slight decrease to $34 \mathrm{PJ}$ in Denmark in 2035, an increase to $56 \mathrm{PJ}$ in Finland in 2030 and an increase to $46 \mathrm{PJ}$ in Sweden in 2035 (Figure 1, Figure 2 and Figure 3).

The pattern of biomass used per technology is very different between the countries, as are the technologies used in the countries. Also the disaggregation of technologies in the national emission inventories differs. Denmark uses 10 groups (with finer underlying disaggregation on age of boiler or stove), Finland currently distinguishes 13 technologies and Sweden 6 technologies.

In Denmark, pellet boilers and stoves (as one group) was the largest consumer of biomass in 2015, followed by new stoves and eco-labelled stoves. The share of fuel used by eco-labelled stoves is projected to increase significantly to 2035 (Figure 1).

In Finland, conventional masonry heaters and masonry ovens in 2015 each used about 9 PJ of wood, followed by manually fed boilers with accumulator tank (8 PJ) and sauna stoves (7 PJ). Wood use in modern boilers and stoves is expected to increase to 2030, while many technologies remain on the same level and only a few older technologies are expected to decrease (Figure 2).

In Sweden, wood boilers (all types grouped together) used $24 \mathrm{PJ}$ out of the total ( 42 PJ), followed by pellet boilers and wood stoves, each consumed about 7 PJ in 2015. In the national projections the shares of fuel used remain similar, but the total use increases from 42 to 46 PJ (Figure 3 ).

Figure 1: Denmark, fuel consumption 2005-2015 and scenarios to 2035 (PJ). (acc.=accumulator tank)

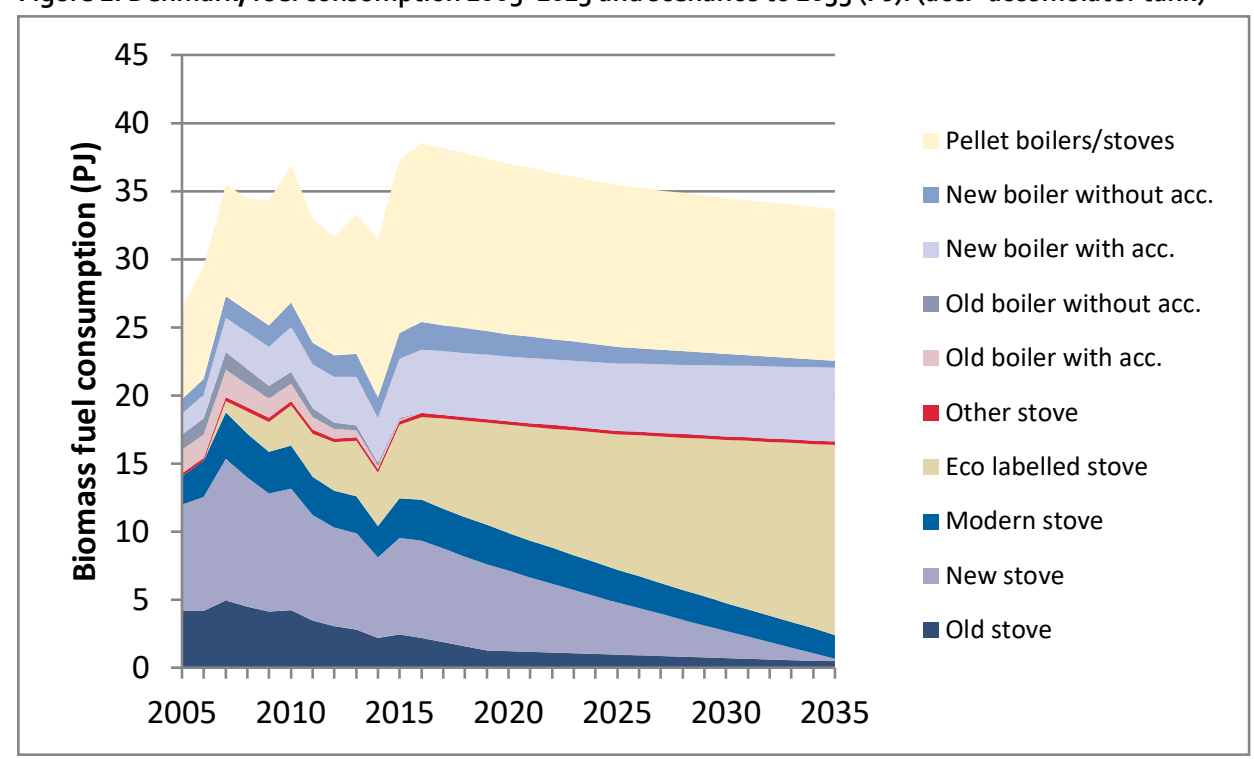

7 Reporting code in NFR- and CRF-tables reported to CLRTAP and UNFCCC 
Figur 2: Biomass fuel consumption in Finland 2005-2015 and projections to 2030 (PJ)

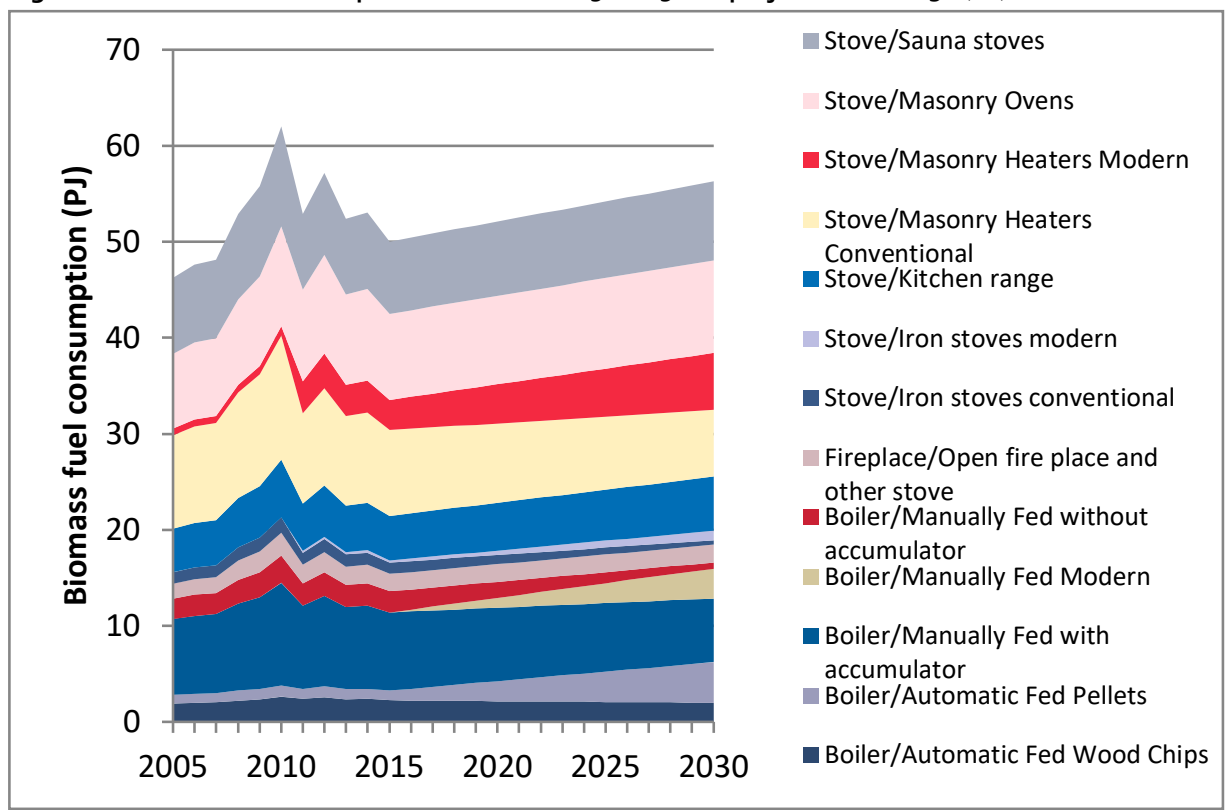

Figure 3: Biomass fuel consumption, Sweden, 2005-2015 and projections to 2035 (PJ)

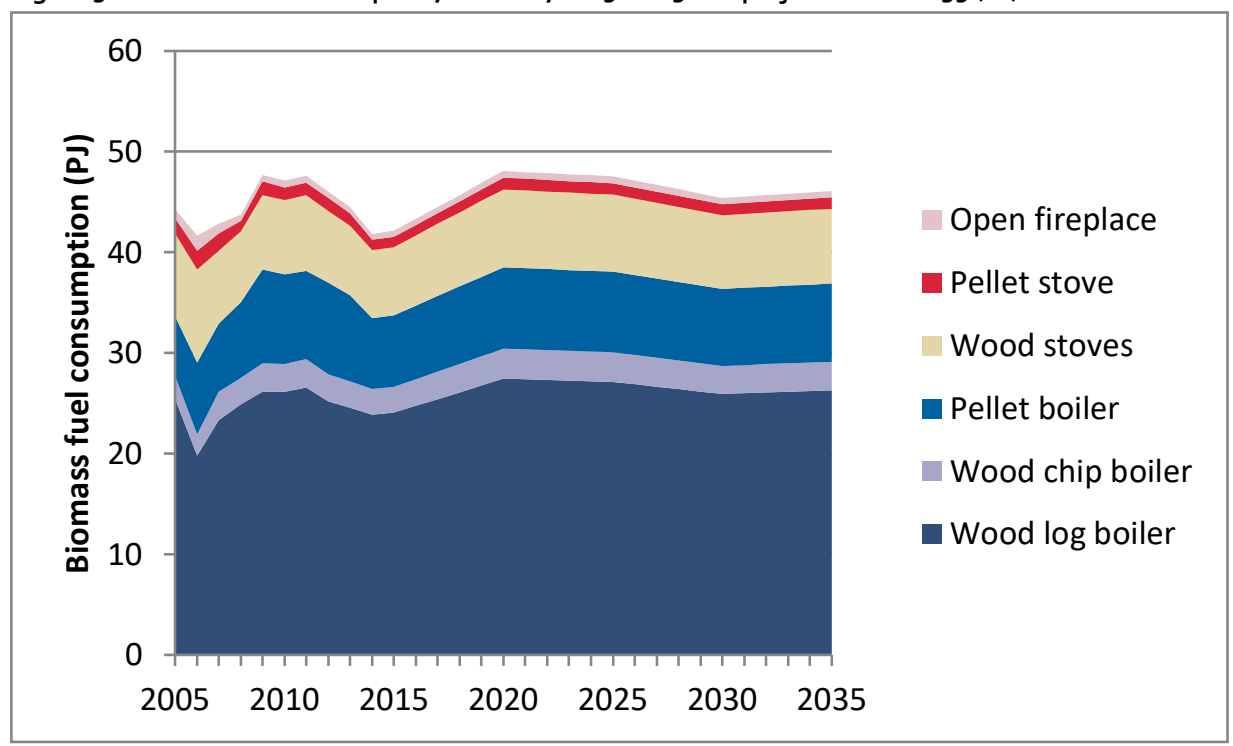

\subsection{Technology specific emission factors}

At present, different equipment, combustion practices and emission factors are used in the countries. In the Nordic SLCP project a measurement program was conducted, where emission factors were developed for a number of residential biomass combustion technologies that are common in the Nordic countries (TN2017:570). 
Obviously not all types and/or age groups of existing technologies could be tested. Certain technologies e.g. sauna stoves that are common in Finland were only included in the measurement program by one appliance. Tests were done during normal combustion conditions, and also at bad combustion conditions (moist fuel, part heat load conditions). Based on the results emission factors for normal and for bad combustion for these technologies were derived.

Technology specific emission factors, the technology groups and ratios for bad combustion developed in the Nordic SLCP-project (TN2017:570) are presented in Table 5 for boilers and in Table 6 for stoves.

Table 5: Emission factors for boilers (mg/MJ). Maximum and minimum values from measurements are given for nominal heat load and standard fuel. The last two columns show the ratio of moist fuel to standard fuel at nominal heat load (N:M/N:S) and the ratio of part load to nominal load using standard fuel (P:S/N:S). Numbers in parenthesis are number of test cycles. (Source: TN2017:570)

\begin{tabular}{|c|c|c|c|c|c|}
\hline & $\begin{array}{r}\text { Nominal load: } \\
\text { Standard fuel } \\
\text { (N:S) }\end{array}$ & $\begin{array}{l}\mathrm{N}: S \\
\mathrm{~min}\end{array}$ & $\begin{array}{l}\mathrm{N}: \mathrm{S} \\
\max \end{array}$ & $\begin{array}{r}\text { Ratio moist fuel } \\
\text { to standard fuel } \\
N: M / N: S\end{array}$ & $\begin{array}{r}\text { Ratio part load } \\
\text { to nominal load } \\
P: S / N: S\end{array}$ \\
\hline Modern log wood boilers & (6) & & & & \\
\hline $\mathrm{PM}_{2.5}$ (mg/MJ) & 35 & 24 & 45 & 1.5 & \\
\hline EC (mg/MJ) & 6 & 2 & 15 & 1.0 & \\
\hline $\mathrm{OC}(\mathrm{mg} / \mathrm{MJ})$ & 15 & 10 & 19 & 1.0 & \\
\hline $\mathrm{CH}_{4}(\mathrm{mg} / \mathrm{MJ})$ & 15 & 4 & 32 & 1.5 & \\
\hline $\operatorname{NMVOC~(mg/MJ)~}$ & 85 & 32 & 141 & 1.5 & \\
\hline $\mathrm{CO}(\mathrm{mg} / \mathrm{MJ})$ & 1160 & 233 & 2037 & 1.0 & \\
\hline Traditional log wood boilers & (2) & & & & \\
\hline PM2.5 (mg/MJ) & 320 & 317 & 320 & 1.5 & 4.0 \\
\hline EC (mg/MJ) & 25 & 19 & 27 & $>1.5$ & 1.0 \\
\hline $\mathrm{OC}(\mathrm{mg} / \mathrm{MJ})$ & 120 & 96 & 138 & $>1.5$ & $>4.0$ \\
\hline $\mathrm{CH}_{4}(\mathrm{mg} / \mathrm{MJ})$ & 75 & 47 & 103 & $>1.5$ & $>3.0$ \\
\hline $\operatorname{NMVOC~(mg/MJ)~}$ & 470 & 462 & 477 & $>1.5$ & $>3.0$ \\
\hline $\mathrm{CO}(\mathrm{mg} / \mathrm{MJ})$ & 3270 & 2963 & 3578 & 1.5 & 2.0 \\
\hline Pellet-fired boilers & (3) & & & & \\
\hline $\mathrm{PM} 2.5$ (mg/MJ) & 35 & 15 & 57 & & 3.0 \\
\hline $\mathrm{EC}(\mathrm{mg} / \mathrm{MJ})$ & 6 & 1 & 14 & & 1.5 \\
\hline OC (mg/MJ) & 10 & 6 & 11 & & 3.5 \\
\hline $\mathrm{CH}_{4}$ (mg/MJ) & 2 & 1 & 4 & & 5.0 \\
\hline $\operatorname{NMVOC~(mg/MJ)~}$ & 15 & 9 & 22 & & 6.0 \\
\hline $\mathrm{CO}(\mathrm{mg} / \mathrm{MJ})$ & 295 & 120 & 631 & & 4.0 \\
\hline Wood chip boiler & (1) & & & & \\
\hline PM2.5 (mg/MJ) & 50 & & & 1.5 & 5.0 \\
\hline $\mathrm{EC}(\mathrm{mg} / \mathrm{MJ})$ & 2 & & & 5.0 & 6.0 \\
\hline $\mathrm{OC}(\mathrm{mg} / \mathrm{MJ})$ & 20 & & & 1.5 & 5.0 \\
\hline $\mathrm{CH}_{4}(\mathrm{mg} / \mathrm{MJ})$ & 5 & & & 3.0 & 15.0 \\
\hline $\operatorname{NMVOC~(mg/MJ)~}$ & 50 & & & 2.0 & 15.0 \\
\hline $\mathrm{CO}(\mathrm{mg} / \mathrm{MJ})$ & 366 & & & 5.0 & 12.0 \\
\hline
\end{tabular}


Table 6: Emission factors for stoves (mg/MJ). Maximum and minimum values from measurements are given for nominal heat load and standard fuel. One column shows the emission factors taking ignition into consideration for modern stoves. The last two columns show the ratio of moist fuel to standard fuel at nominal heat load (N:M/N:S) and the ratio of part load to nominal load using standard fuel (P:S/N:S). Numbers in parenthesis are number of test cycles. (Source: TN2017:570)

\begin{tabular}{|c|c|c|c|c|c|c|}
\hline & $\begin{array}{r}\text { Nominal } \\
\text { load: } \\
\text { Standard } \\
\text { fuel }\end{array}$ & $\begin{array}{l}\mathrm{N}: \mathrm{S} \\
\mathrm{min}\end{array}$ & $\begin{array}{l}\text { N:S } \\
\max \end{array}$ & $\begin{array}{r}\mathrm{N}: \mathrm{S} \\
\text { including } \\
\text { ignition }\end{array}$ & $\mathrm{N}: \mathrm{M} / \mathrm{N}: \mathrm{S}$ & P:S/N:S \\
\hline Modern stoves (incl state-of-the-art) & (8) & & & & & \\
\hline $\mathrm{PM} 2.5$ (mg/MJ) & 84 & 60 & 106 & 105 & 5.0 & 2.0 \\
\hline $\mathrm{EC}(\mathrm{mg} / \mathrm{MJ})$ & 20 & 3 & 42 & 25 & 1.0 & 1.0 \\
\hline $\mathrm{OC}(\mathrm{mg} / \mathrm{MJ})$ & 24 & 6 & 39 & 41 & 8.0 & 2.5 \\
\hline $\mathrm{CH}_{4}(\mathrm{mg} / \mathrm{MJ})$ & 90 & 31 & 153 & 90 & 2.0 & 1.5 \\
\hline NMVOC (mg/MJ) & 76 & 19 & 144 & 96 & 5.0 & 2.0 \\
\hline $\mathrm{CO}(\mathrm{mg} / \mathrm{MJ})$ & 1582 & 919 & 2287 & 1582 & 2.0 & 1.5 \\
\hline Older stove & (1) & & & & & \\
\hline $\mathrm{PM} 2.5$ (mg/MJ) & 147 & & & & & 2.5 \\
\hline $\mathrm{EC}(\mathrm{mg} / \mathrm{MJ})$ & 13 & & & & & 1.0 \\
\hline $\mathrm{OC}(\mathrm{mg} / \mathrm{MJ})$ & 47 & & & & & 3.5 \\
\hline $\mathrm{CH}_{4}(\mathrm{mg} / \mathrm{MJ})$ & 49 & & & & & 3.0 \\
\hline NMVOC (mg/MJ) & 132 & & & & & 2.5 \\
\hline $\mathrm{CO}(\mathrm{mg} / \mathrm{MJ})$ & 1165 & & & & & 2.0 \\
\hline Tiled and masonry stove & (2) & & & & & \\
\hline $\mathrm{PM}_{2.5}$ (mg/MJ) & 140 & 82 & 198 & & 1.0 & 2.0 \\
\hline $\mathrm{EC}(\mathrm{mg} / \mathrm{MJ})$ & 72 & 22 & 122 & & 1.0 & 1.5 \\
\hline $\mathrm{OC}(\mathrm{mg} / \mathrm{MJ})$ & 51 & 31 & 70 & & 1.0 & 2.0 \\
\hline $\mathrm{CH}_{4}(\mathrm{mg} / \mathrm{MJ})$ & 114 & 61 & 167 & & 1.0 & 2.0 \\
\hline NMVOC (mg/MJ) & 181 & 133 & 229 & & 1.0 & 1.0 \\
\hline $\mathrm{CO}(\mathrm{mg} / \mathrm{MJ})$ & 2365 & 1585 & 3145 & & 1.0 & 1.0 \\
\hline Pellet stove & (1) & & & & & \\
\hline $\mathrm{PM} 2.5$ (mg/MJ) & 100 & & & & & 1.5 \\
\hline $\mathrm{EC}(\mathrm{mg} / \mathrm{MJ})$ & 10 & & & & & 1.0 \\
\hline $\mathrm{OC}(\mathrm{mg} / \mathrm{MJ})$ & 6 & & & & & 1.0 \\
\hline $\mathrm{CH}_{4}(\mathrm{mg} / \mathrm{MJ})$ & 1 & & & & & 2.5 \\
\hline NMVOC (mg/MJ) & 4 & & & & & 3.5 \\
\hline $\mathrm{CO}(\mathrm{mg} / \mathrm{MJ})$ & 189 & & & & & 2.5 \\
\hline Sauna stove & (1) & & & & & \\
\hline $\mathrm{PM} 2.5$ (mg/MJ) & 104 & & & & 1.5 & \\
\hline $\mathrm{EC}(\mathrm{mg} / \mathrm{MJ})$ & 52 & & & & 1.0 & \\
\hline $\mathrm{OC}(\mathrm{mg} / \mathrm{MJ})$ & 15 & & & & 2.0 & \\
\hline $\mathrm{CH}_{4}(\mathrm{mg} / \mathrm{MJ})$ & 43 & & & & 2.0 & \\
\hline NMVOC (mg/MJ) & 85 & & & & 2.0 & \\
\hline $\mathrm{CO}(\mathrm{mg} / \mathrm{MJ})$ & 1405 & & & & 1.5 & \\
\hline
\end{tabular}

\subsection{Adapted activity data - combustion technologies}

The technology specific emission factors were divided into four categories for boilers and five categories for stoves. These do not align exactly with the national technologies in the national emission inventories or projections and therefore the national activity data on technologies and their respective fuel use was categorised into the emission factors developed in the measurement programme.

For the Swedish data the current 6 categories of technologies were split and adapted on more categories, while the Danish and Finnish categories were aggregated 
or otherwise aligned with the emission factor categories. Table 7 shows how the adaptation of technologies was done. Fuel consumption was adapted accordingly.

Table 7: Adaptation of national technology splits to emission factor (EF) technology categories

\begin{tabular}{|c|c|}
\hline National technology split & EF technology category \\
\hline \multicolumn{2}{|l|}{ Denmark } \\
\hline Old stove & Older stoves \\
\hline New stove & Older stoves \\
\hline Modern stove (-2015) & Older stoves \\
\hline Modern stove (2015-) & Modern stoves \\
\hline Eco labelled stove & Modern stoves \\
\hline Other stove & Older stoves \\
\hline Old boiler with accumulator & Traditional wood log boiler \\
\hline Old boiler without accumulator & Traditional wood log boiler \\
\hline New boiler with accumulator & Modern log wood boiler \\
\hline New boiler without accumulator & Modern log wood boiler \\
\hline Pellet boilers/stoves & Pellet fired boiler \\
\hline \multicolumn{2}{|l|}{ Finland } \\
\hline Boiler/Automatic Fed Wood Chips & Wood chip boiler \\
\hline Boiler/Automatic Fed Pellets & Pellet fired boiler \\
\hline Boiler/Manually Fed with accumulator & Modern log wood boiler \\
\hline Boiler/Manually Fed Modern & Modern log wood boiler \\
\hline Boiler/Manually Fed without accumulator & Traditional wood log boiler \\
\hline Fireplace/Open fire place and other stove & Older stoves \\
\hline Stove/Iron stoves conventional & Older stoves \\
\hline Stove/Iron stoves modern & Modern stoves \\
\hline Stove/Kitchen range & Older stoves \\
\hline Stove/Masonry Heaters Conventional & Tiled and masonry stoves \\
\hline Stove/Masonry Heaters Modern & Modern stove \\
\hline Stove/Masonry Ovens & Modern stove \\
\hline Stove/Sauna stoves & Sauna stove \\
\hline \multicolumn{2}{|l|}{ Sweden } \\
\hline Wood log boiler & Modern log wood boiler \\
\hline -"- & Traditional wood log boiler \\
\hline Wood chip boiler & Wood chip boiler \\
\hline Pellet boiler & Pellet fired boiler \\
\hline Wood stoves & Modern stoves \\
\hline -"- & Older stoves \\
\hline -"- & Tiled and masonry stoves \\
\hline Pellet stove & Pellet stove \\
\hline Open fireplace & Older stove \\
\hline
\end{tabular}

When a national technology category is split into two (or three) emission factor technology categories, as was done for Sweden, assumptions on the shares were done for the time series (Table 8). The values represent the percentage of fuel use in Sweden by combustion technology (split on boiler and stove). 
Table 8: Assumptions on technology development in Sweden 1990-2035

\begin{tabular}{llrrr}
\hline National category & Technology split & \multicolumn{2}{c}{ Distribution of fuel } \\
& & & 2015 & 2035 \\
\hline \multirow{2}{*}{ Boilers } & Modern wood log boiler & $1990-1995$ & $60 \%$ & $85 \%$ \\
& Traditional wood log boiler & $0 \%$ & $40 \%$ & $15 \%$ \\
\hline \multirow{2}{*}{ Stoves } & Modern stoves & $100 \%$ & $50 \%$ & $75 \%$ \\
& Older stoves & & $46 \%$ & $21 \%$ \\
& Tiled stoves & $96 \%$ & $4 \%$ & $4 \%$ \\
\hline
\end{tabular}

The baseline assumptions on fuel distribution on technologies for 1990 and 2015 are documented in Gustafsson and Helbig (2017). Assumptions are based on information from the residential survey from Swedish Energy Agency, interviews with several chimney sweepers, and MSB statistics on number of boilers.

Projected activity data from the Swedish Energy Agency is grouped by fuel type (wood logs, pellets and wood chips) and main combustion technology (boiler and stove). In Gustafsson and Helbig (2017), modern boilers are assumed to be introduced in the early 90 's and by 2015 to account for $60 \%$ of the wood logs used by boilers. In this study, the projected exchange rate from old to modern boilers till 2035 is assumed to be about $1.25 \%$ annually. Modern stoves are assumed to account for $50 \%$ of the wood logs used in 2015 and about $75 \%$ in 2035.

\subsection{Calculation of health impact}

The changes in health impact from estimated changes in emissions between current technology status and the technology/user behaviour scenario(s) were calculated through the impact pathway approach (Bickel et al3. 2005). The emission scenarios produced in this project were introduced to the scenario analysis version of the Greenhouse Gas - Air Pollution Interactions and Synergies (GAINS) model and output from the GAINS model was introduced to the the Alpha-RiskPoll (ARP) model (Amann, 2012; Holland et al., 2012). More specifically, scenario-specific PM2.5 emissions from residential wood combustion in Denmark, Finland and Sweden were uploaded to the GAINS model. The GAINS model is for each scenario used to calculate emission dispersion and resulting population-weighted average concentration of PM2.5 in ambient air for European countries. These results are then transferred from the GAINS model and used as input to the ARP model scenarios. With the ARP-model scenariospecific regional impacts of air pollution on human health (reduced life expectancy, chronic bronchitis, hospital admissions etc.) were calculated for all countries affected by PM2.5 emission changes in Denmark, Finland, and Sweden.

The ARP model use demographic estimates for the countries based on population projections from the United Nations (2011). The relationships (Exposure-Response Coefficients) between ambient concentration of PM2.5 and health impacts are taken 
from the World Health Organization (2013). The health impacts included in the health impact assessment are shown in Table 9.

Table 9: PM2.5-related health impacts considered in this study

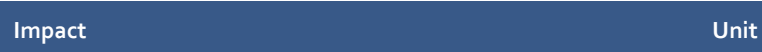

Mortality (All ages)

Mortality (30yr +)

Infant Mortality (0-1yr)

Chronic Bronchitis (27yr + )

Bronchitis in children aged 6 to

Respiratory Hospital Admissions (All ages)

Cardiac Hospital Admissions (>18 years)

Restricted Activity Days (all ages)

Asthma symptom days (children 5-19yr)

Lost working days (15-64 years)

Life years lost

Premature deaths

Premature deaths

Cases

Cases

Cases

Cases

Days

Days

Days

\subsection{Calculations of climate impact}

The estimated changes in emissions between current technology status and the technology/user behaviour scenario(s) were transformed to $\mathrm{CO}_{2}$ equivalents using climate metrics for the SLCPs from IPCC (2013). The specific climate metric used is the Global Warming Potential with a 100 years' time perspective (GWP100). This metric was chosen since it is the most common and used in climate policies today. The theoretical potential change in climate impact was then compared with currently reported greenhouse gas emissions in the countries for illustrative purposes.

Climate impacts of the different scenarios were calculated by using total emission estimates for each scenario and multiplying with the respective GWP10o value for each pollutant. Table 10 show the GWP10o values to calculate climate impacts of scenariospecific emissions from wood combustion in Denmark, Finland, and Sweden

Table 10: GWP100 values for European emissions of $\mathrm{CH}_{4}, \mathrm{NMVOC}, \mathrm{BC} / \mathrm{EC}$ and OC (IPCC, 2013)

$\begin{array}{lcccr} & \mathrm{CH}_{4} & \text { NMVOC } & \text { BC/EC } & \text { OC } \\ \text { Low } & & & 138 & -26 \\ \text { Mid } & 28 & 3 & 345 & -46 \\ \text { High } & 28 & 6 & 552 & -66\end{array}$




\section{Activity data and emission scenarios}

\subsection{Definition of scenarios and assumptions}

National projections, with existing measures (WEM) are those officially reported from the countries. The national projections use the national technology split and national emission factors. The national projections are presented for comparison with the scenarios developed in this project.

Six realistic scenarios for the three Nordic countries were defined (Table 11). They comprise two different basic scenarios for technology development. Scenarios 1-3 have the same activity data, which is an adaptation of activity data from the national WEM projections, where fuel used in the national technology categories were assigned to the emission factor groups from the measurement program in the Nordic SLCP project. In scenarios 4-6 all fuel for boilers and stoves, respectively, is assigned to modern boilers and modern stoves in 2035 , and no traditional boilers or older stoves are assumed to be used. No changes were introduced for the remaining combustion technologies.

Each of the two activity data scenarios are split in three scenarios for combustion behaviour. The three defined "behaviours" are "expected behaviour" which is defined as $10 \%$ bad combustion, "worse than expected" is defined as $20 \%$ bad combustion and "good combustion", which is defined as only good combustion ( $0 \%$ bad). The scenario on "expected behaviour" is based on the present assumption on extent of bad combustion in Finland and Sweden. The two other scenarios on combustion behaviour (20\% and $0 \%$ bad combustion) were chosen to be realistic and relevant in terms of emission reduction potential. The emission factors used were weighted accordingly using information from Table 5 and Table 6. To derive the emission factors for bad combustion conditions the following weighting of the emission factors were used: $10 \%$ bad $=5 \%$ moist and $5 \%$ part load, $20 \%$ bad $=10 \%$ moist and $10 \%$ part load. If only one of the cases (moist fuel or part load) was available for a certain technology group, this factor was used. 
Table 11: Definition of scenarios

\begin{tabular}{|c|c|c|c|c|}
\hline & Scenario & $\begin{array}{l}\text { Only modern } \\
\text { technology for } \\
\text { boilers and stoves }\end{array}$ & Behaviour & $\begin{array}{r}\text { Share of bad } \\
\text { combustion }\end{array}$ \\
\hline National projections & $\begin{array}{l}\text { With existing measures } \\
\text { (WEM), baseline }\end{array}$ & & & \\
\hline Adapted baseline & $\mathrm{SC}_{1}$ & No & expected & $10 \%$ \\
\hline -"- & $\mathrm{SC}_{2}$ & No & worse than expected & $20 \%$ \\
\hline -"- & $\mathrm{SC}_{3}$ & No & good & $0 \%$ \\
\hline Modern technologies & $\mathrm{SC}_{4}$ & Yes & expected & $10 \%$ \\
\hline -"- & $\mathrm{SC}_{5}$ & Yes & worse than expected & $20 \%$ \\
\hline -"- & $\mathrm{SC} 6$ & Yes & good & $0 \%$ \\
\hline
\end{tabular}

The definitions of the scenarios imply that possible technological changes from traditional/older to modern appliances for e.g. pellet boilers, wood chip boilers or sauna stoves are not taken into account. Masonry heaters in Finland constitute a big share of the fuel use. The modern masonry heaters are assumed to be modern stoves, but in the scenarios 4-6 we have not assumed any additional exchange of conventional masonry heaters to modern ones, since this was not seen as realistic given that they are seldom replaced as they are built into the house and modern masonry heaters are assumed to be built in new houses.

In Denmark and Sweden bad combustion is assumed to be included in the currently used national emission factors, but no specific share is used. In the Finnish emission inventory for residential combustion, the approach of assuming a share of bad combustion, and weighting this into the emission factors is already in use based on Savolahti et al. (2014).

\subsection{Activity data scenarios}

In order to use the technology group specific emission factors (Table 5 and Table 6), an adaptation of the nationally projected activity data was needed. The total fuel use was retained from the national data, but the technologies in the national projections were adapted to the emission factors technology groups (as presented in Table 7). The adapted activity data baseline per emission factor technology group (used in scenarios 1-3) is shown in Figure 4. In the modern technology scenarios (scenarios 4-6) the fuel used in older stoves is assumed to be used in modern stoves in 2035 , and the fuel used in traditional wood log boilers is assumed to be used in modern log wood boilers. No other changes are introduced.

As can be seen in Figure 4 the changes from the adapted baseline to the modern technology scenarios are small. The actual changes are that $5 \mathrm{PJ}$ fuel is assumed to be combusted in modern stoves instead of in older stoves, and another $5 \mathrm{PJ}$ in modern boilers instead of in traditional boilers in 2035 . This change, $10 \mathrm{PJ}$ out of a total of $\sim 150$ $\mathrm{PJ}$, means that in scenarios $4-6$ with modern technologies, only about $6-7 \%$ of the total fuel use is affected, while the remaining fuel is used in the same technologies in all 
scenarios. These small changes are explained by the national projections already assuming a significant shift towards modern stoves and boilers with existing measures (WEM) in place.

Figure 4: Biomass fuel consumption in the adapted baseline technology categories (PJ) in Denmark, Finland and Sweden (scenarios 1-3). In scenarios 4-6 the fuel used in older stoves and in traditional boilers in 2035 is moved to modern stoves and modern boilers, respectively (red circles)

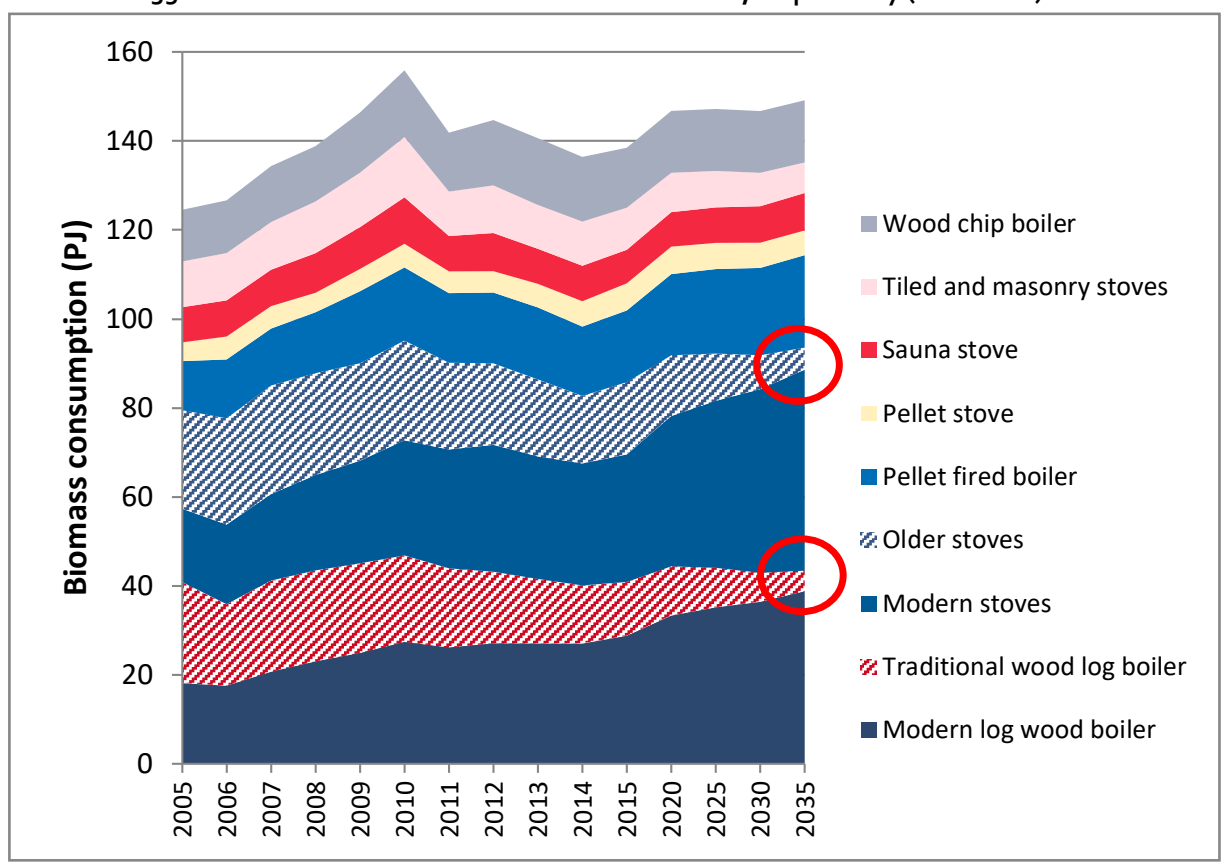

\subsection{Brief comparison of national emissions (WEM) and expected scenario (SC1)}

National emission projections, with existing measures (WEM), are those officially reported from the countries. The national emission projections use the national technology split and national emission factors. The estimated emissions in $\mathrm{SC}_{1}$ (the expected scenario) developed in this project are based on the adapted activity data, with expected combustion behaviour and technology specific emissions factors from TN2017:570.

A comparison of estimated emissions from total residential biomass use, as a sum for the three Nordic countries, in the current national projections (WEM) and the $\mathrm{SC}_{1}$ scenario in 2035 are presented in Table 12. The emissions in the aggregated national projections (WEM) are higher than the scenario 1 results, especially for $\mathrm{BC}$ and $\mathrm{CH}_{4}$. For $\mathrm{BC}$ and $\mathrm{CH}_{4}$ the emissions in the $\mathrm{SC}_{1}$ scenario are about half compared to the WEM scenarios in 2035, while $\mathrm{NMVOC}$ and $\mathrm{PM}_{2.5}$ in $\mathrm{SC}_{1}$ are about 60 and $70 \%$ of emissions according to WEM. Organic carbon, $\mathrm{OC}$, is only available in the national projections from Finland, so no sum for the three Nordic countries WEM projections is available for comparison. 
The differences in estimated emissions between the expected scenario $\mathrm{SC}_{1}$ and the reported national WEM projections are to a large extent due to differences in national emission factors in the WEM projections compared to the technology specific factors used in the scenarios in this study, and also to some extent due to the adaptation of national activity data into the technology split.

The WEM projections are not further discussed in this report.

\begin{tabular}{|c|c|c|c|}
\hline Pollutant & Scenario & 2035 kt emissions & $\mathrm{SC}_{1} / \mathrm{WEM}$ \\
\hline \multirow[t]{2}{*}{$\mathrm{CH}_{4}$} & WEM & 15.9 & \multirow[t]{2}{*}{$48 \%$} \\
\hline & $\mathrm{SC}_{1}$ & 7.6 & \\
\hline \multirow[t]{2}{*}{$B C$} & WEM & 4.8 & \multirow{2}{*}{$54 \%$} \\
\hline & $\mathrm{SC}_{1}$ & 2.6 & \\
\hline \multirow[t]{2}{*}{$\mathrm{PM} 2.5$} & WEM & 18.2 & \multirow[t]{2}{*}{$71 \%$} \\
\hline & $\mathrm{SC}_{1}$ & 12.9 & \\
\hline \multirow[t]{2}{*}{ NMVOC } & WEM & 26.1 & \multirow{2}{*}{$61 \%$} \\
\hline & $\mathrm{SC}_{1}$ & 16.1 & \\
\hline
\end{tabular}

\subsection{Emission scenario results}

All estimated emissions presented below are calculated based on the total biomass combusted including all technologies, which for 2035 means around $150 \mathrm{PJ}$ as a sum for Denmark, Finland and Sweden.

The most interesting emission scenarios $\left(\mathrm{SC}_{1}, \mathrm{SC}_{2}, \mathrm{SC}_{4}, \mathrm{SC} 6\right)$ of methane $\left(\mathrm{CH}_{4}\right)$, Black Carbon (BC), PM2.5, NMVOC and Organic Carbon (OC) 2020-2035 for the three Nordic countries as a whole are presented in Figure 5 to Figure $9 \mathrm{SC}_{1}$, the expected scenario, was also back-calculated for 2005-2015 as a historical reference.

The highest and lowest estimated emissions can be found in $\mathrm{SC}_{2}$ and SC6, respectively. $\mathrm{SC}_{2}$, the worst of the scenarios, is based on adapted baseline activity data including older technologies for boilers and stoves, and an assumed share of bad combustion of $20 \%$. In SC6, the best scenario, boilers and stoves are modern technology, and no bad combustion is assumed.

A change to modern technologies for boilers and stoves in 2035 leads to lower emissions ( $\mathrm{SC}_{1}$ compared to $\mathrm{SC}_{4}$ ). Figure 5 to Figure 9 also show that the combustion behaviour affects the emissions for all substances except $\mathrm{BC}$ ( $\mathrm{SC}_{1}$ vs $\mathrm{SC}_{2}$ and $\mathrm{SC}_{4}$ vs SC6). The defined combustion behaviour for each scenario is kept the same for the time series.

Estimated emissions in the remaining scenarios $\left(\mathrm{SC}_{3}\right.$ - Adapted baseline activity data and good combustion behaviour; $\mathrm{SC}_{5}$-All modern technology in 2035 and worse than expected combustion behaviour) lie within the ranges of SC2 and SC6. 
Figure 5: Estimated total emissions of methane $\left.\mathrm{CH}_{4}\right)$ from residential combustion of biomass in scenario 1, 2, 4 and 6 (ktonnes) as a sum for Denmark, Finland and Sweden

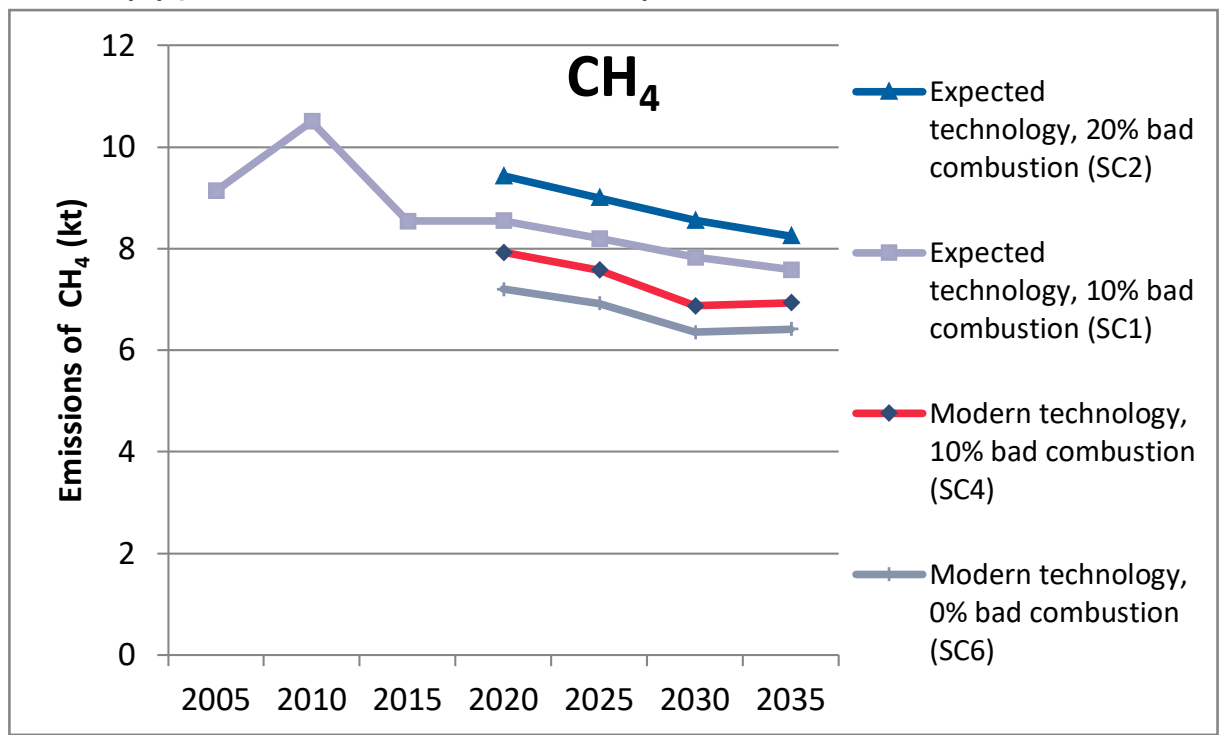

Figure 6: Estimated total emissions of $\mathrm{BC}$ from residential combustion of biomass in the scenarios and according to current national projections (WEM) (ktonnes) as a sum for Denmark, Finland and Sweden

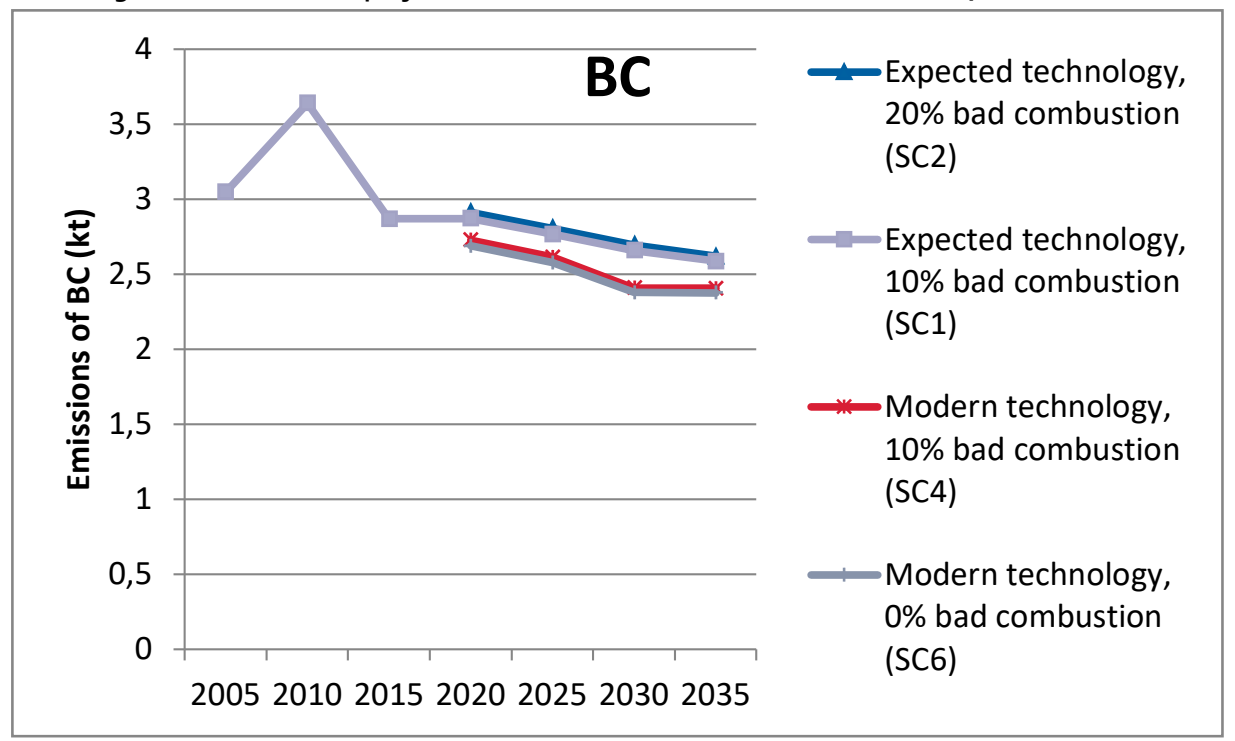


Figure 7: Estimated total emissions of PM2.5 from residential combustion of biomass in the scenarios and according to current national projections (WEM) (ktonnes) as a sum for Denmark, Finland and Sweden

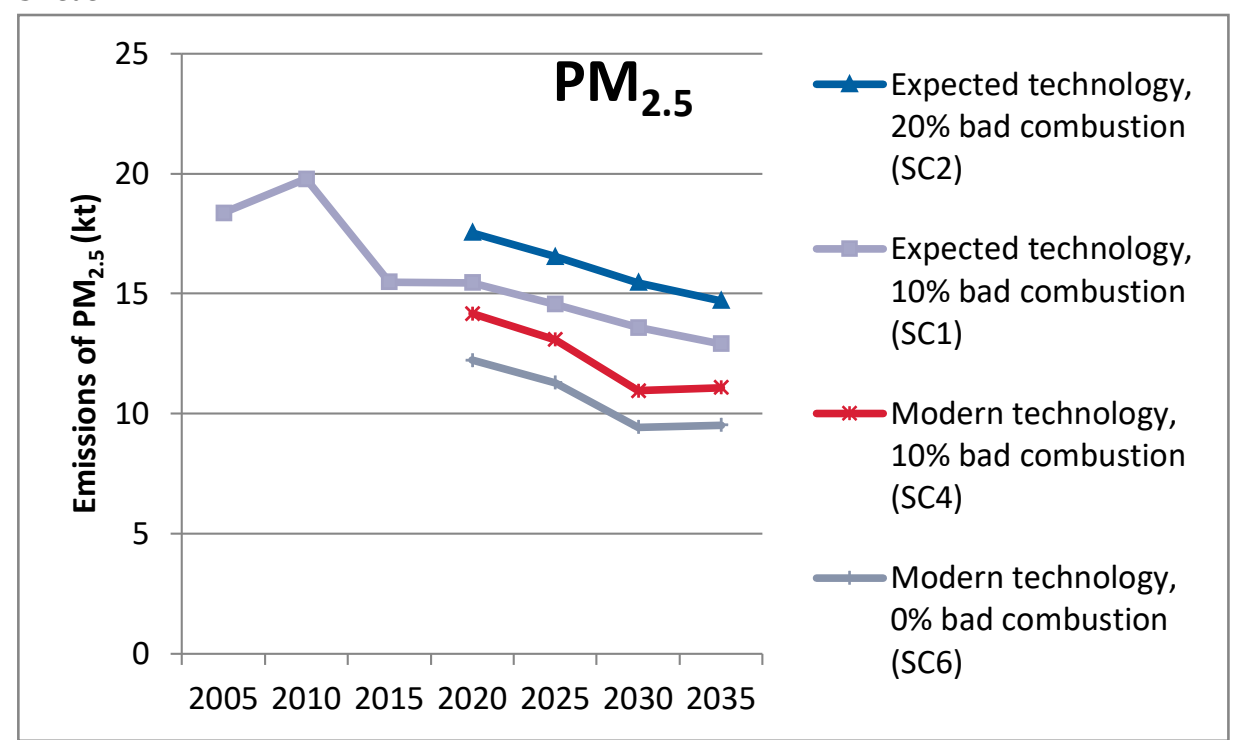

Figure 8: Estimated total emissions of NMVOC from residential combustion of biomass in the scenarios and according to current national projections (WEM) (ktonnes) as a sum for Denmark, Finland and Sweden

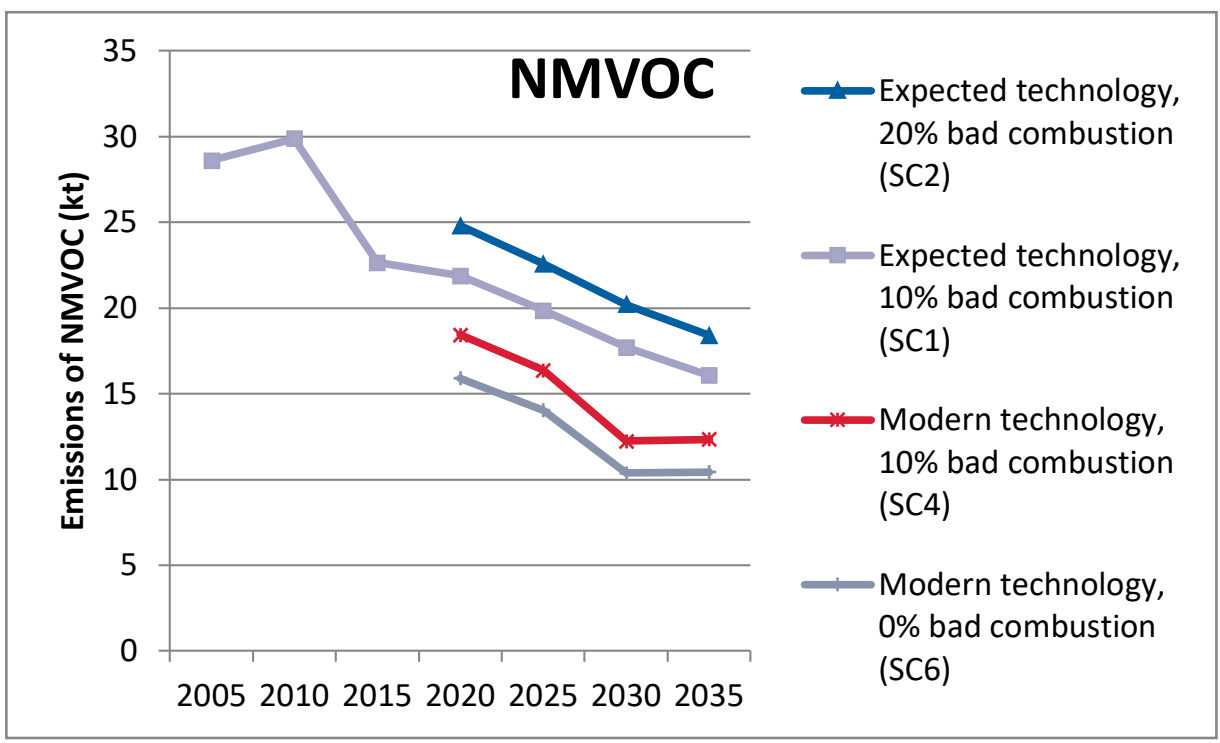


Figure 9: Estimated total emissions of $O C$ from residential combustion of biomass in the scenarios (ktonnes) ) as a sum for Denmark, Finland and Sweden

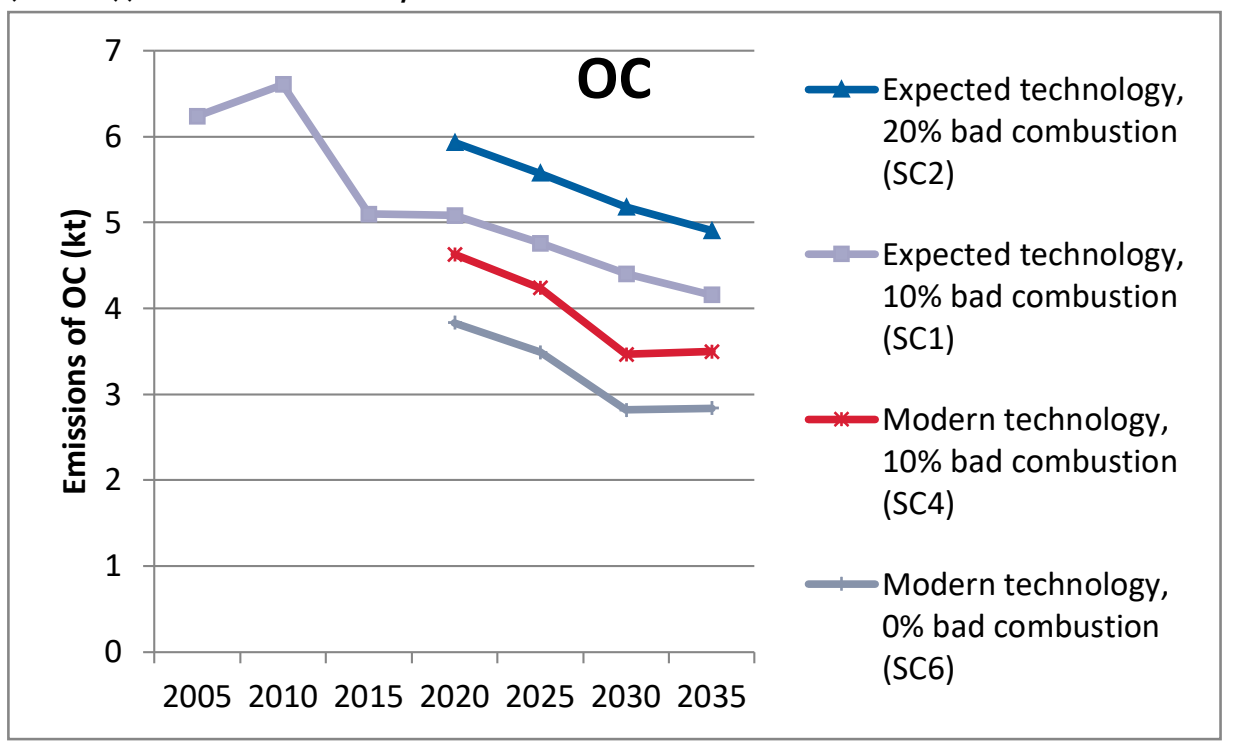

The total emissions from residential combustion of biomass in Denmark, Finland and Sweden in 2035 according to the worst scenario $\left(S_{2}\right)$, expected $\left(S_{1}\right)$, modern technology and expected behaviour $\left(\mathrm{SC}_{4}\right)$ and the best scenario $(\mathrm{SC} 6)$ are shown in Table 13 and Figure 10.

The impact of modern technologies for $10 \mathrm{PJ}$ out of $150 \mathrm{PJ}$ ( $7 \%$ of the combusted fuel), the difference between $\mathrm{SC}_{1}$ to $\mathrm{SC}_{4}$ is a reduction of emissions of $23 \%$ for NMVOC, around $15 \%$ for $\mathrm{PM}_{2} .5$ and $\mathrm{OC}$, and $7 \%$ and $9 \%$ respectively for $\mathrm{BC}$ and $\mathrm{CH}_{4}$. Even though the activity data change is rather small the emissions are reduced rather significantly.

Between the expected $\left(\mathrm{SC}_{1}\right)$ and best scenario ( $\left.\mathrm{SC} 6\right)$, estimated emissions are reduced even more, by $26 \%$ for $\mathrm{PM}_{2} .5$, by $32-35 \%$ for OC and $\mathrm{NMVOC}_{\text {, while }} \mathrm{CH}_{4}$ is reduced by $15 \%$ and $\mathrm{BC}$ by $8 \%$. Going from the worst (SC2) to the best (SC6) scenario of course gives the largest emission reductions, $>40 \%$ for NMVOC and OC, 35\% for PM2.5, around $20 \%$ for $\mathrm{CH}_{4}$ and almost $10 \%$ for $\mathrm{BC}$. 
Table 13: Estimated total emissions from residential combustion of biomass in Denmark, Finland and Sweden in 2035 (ktonnes) in scenarios SC2, SC1, SC4 and SC6 and reductions in \%

\begin{tabular}{|c|c|c|c|c|c|}
\hline Year 2035 & $\mathrm{CH}_{4}$ & NMVOC & PM2.5 & $\mathrm{BC}$ & OC \\
\hline $\begin{array}{l}\text { SC2 some old technology, bad combustion } \\
\text { (Adapted AD and } 20 \% \text { bad combustion) }\end{array}$ & 8.2 & 18.4 & 14.7 & 2.6 & 4.9 \\
\hline $\begin{array}{l}\text { SC1 Expected, some old technology, expected combustion } \\
\text { (Adapted AD and 10\% bad combustion) }\end{array}$ & 7.6 & 16.1 & 12.9 & 2.6 & 4.2 \\
\hline $\begin{array}{l}\mathrm{SC}_{4} \text { Modern technology, expected combustion } \\
\text { (All modern technology in } 2035 \text { and 10\% bad combustion) }\end{array}$ & 6.9 & 12.3 & 11.1 & 2.4 & 3.5 \\
\hline $\begin{array}{l}\text { SC6 Modern technology, good combustion } \\
\text { (All modern technology in } 2035 \text { and o\% bad combustion) }\end{array}$ & 6.4 & 10.4 & 9.5 & 2.4 & 2.8 \\
\hline Reduction ( $\mathrm{SC}_{1}-\mathrm{SC} 6$ ), expected to best & $15 \%$ & $35 \%$ & $26 \%$ & $8 \%$ & $32 \%$ \\
\hline Reduction ( $\left.\mathrm{SC}_{1}-\mathrm{SC}_{4}\right)$, impact of modern technology & $9 \%$ & $23 \%$ & $14 \%$ & $7 \%$ & $16 \%$ \\
\hline Reduction (SC2 $-\mathrm{SC} 6$ ), worst to best & $22 \%$ & $43 \%$ & $35 \%$ & $9 \%$ & $42 \%$ \\
\hline
\end{tabular}

Figure 10: Estimated total emissions from residential combustion of biomass from Denmark, Finland and Sweden in 2035 in the worst scenario (SC2), expected scenario (SC1), modern technology (SC4), and the best scenario (SC6)

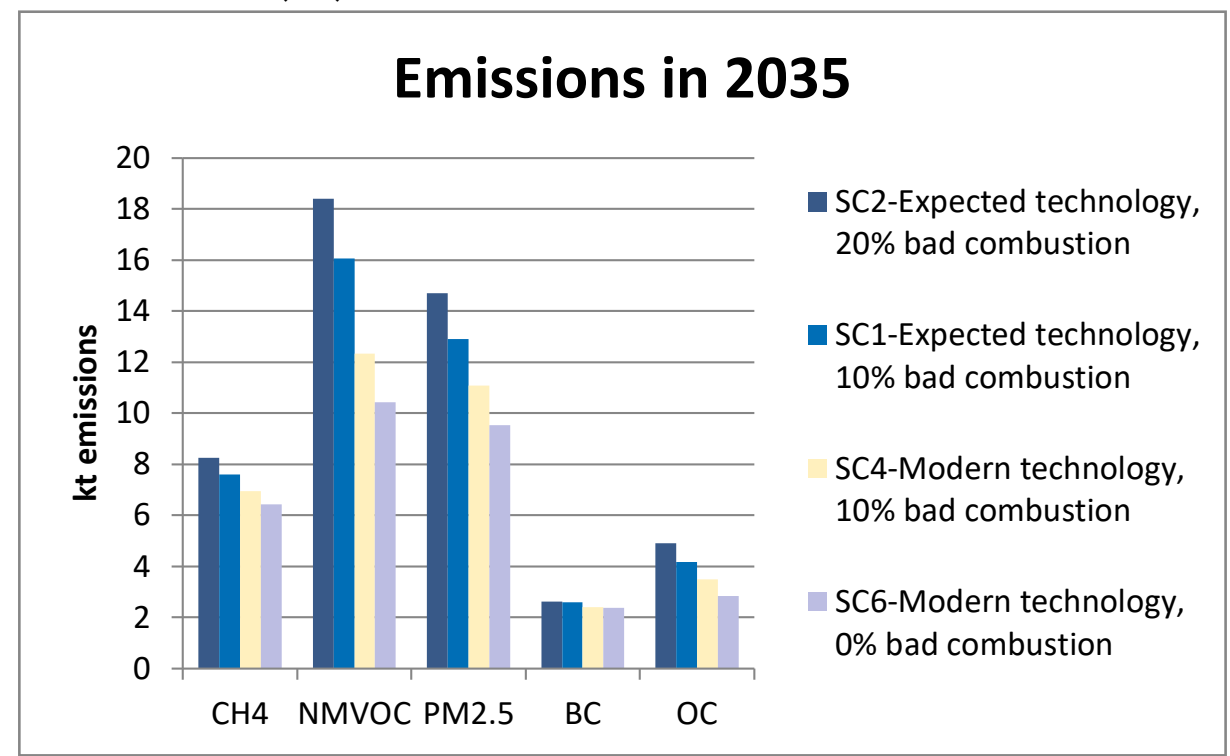




\section{Health and climate impacts}

\subsection{Health impact}

For health impacts from reduced emissions of PM2.5 the total numbers are of less relevance since the total numbers are based on many scenario assumptions left outside the focus of this project (for example future PM2.5 emissions originating from other countries). If focusing only on the difference between our scenarios we can see that poor behaviour during combustion (difference between $\mathrm{SC}_{3}$ and $\mathrm{SC}_{2}$ ) would risk increasing Northern European health impacts (Table 14).

Table 14: Estimated PM2.5-related health impacts in Europe as response to poor combustion behaviour in Denmark, Finland and Sweden in 2035

$\begin{array}{lr}\text { Impact } & \text { Unit } \\ \text { Mortality (All ages) } & 851 \quad \text { Life years lost } \\ \text { Mortality (30yr +) } & 107 \text { Premature deaths } \\ \text { Infant Mortality (0-1yr) } & 0 \quad \text { Premature deaths } \\ \text { Chronic Bronchitis (27yr +) } & 79 \text { Cases } \\ \text { Bronchitis in children aged 6 to } & 281 \text { Cases } \\ \text { Respiratory Hospital Admissions (All ages) } & 41 \text { Cases } \\ \text { Cardiac Hospital Admissions (>18 years) } & 29 \text { Cases } \\ \text { Restricted Activity Days (all ages) } & 115,229 \text { Days } \\ \text { Asthma symptom days (children 5-19yr) } & 2,580 \text { Days } \\ \text { Lost working days (15-64 years) } & 22,538 \text { Days }\end{array}$

Note: The mortality is estimated with two different units, using them both would imply double counting.

Improved technologies would have the opposite but smaller impact on human health (going from SC1 to $\mathrm{SC}_{4}$ ) (Table 15).

Table 15: Estimated PM2.5-related health impacts in Europe as response to the use of best available technology in Denmark, Finland and Sweden in 2035

Impact Unit

Mortality (All ages)

Mortality (3oyr + )

Infant Mortality (o-1yr)

Chronic Bronchitis (27yr +)

Bronchitis in children aged 6 to

Respiratory Hospital Admissions (All ages)

Cardiac Hospital Admissions (>18 years)

Restricted Activity Days (all ages)

Asthma symptom days (children 5-19yr)

Lost working days (15-64 years)
Unit

$\begin{aligned}-348 & \text { Life years lost } \\ -43 & \text { Premature deaths } \\ 0 & \text { Premature deaths } \\ -33 & \text { Cases } \\ -121 & \text { Cases } \\ -14 & \text { Cases } \\ -11 & \text { Cases } \\ -48,961 & \text { Days } \\ -1,011 & \text { Days } \\ -9,543 & \text { Days }\end{aligned}$

Note: The mortality is estimated with two different units, using them both would imply double counting. 
If comparing the worst with the best available technology and assumed combustion behaviour ( $\mathrm{SC}_{2}$ and $\mathrm{SC} 6$ ) it can be seen that different strategies towards residential wood combustion practices could affect roughly 1000 premature deaths annually by 2035 (Table 16).

Table 16: Estimated PM2.5-related health impacts in Europe as response to the use of good combustion behaviour and best available technology in Denmark, Finland and Sweden in 2035 (note that mortality is estimated with two different units, using them both would imply double counting)

Impact $\quad$ Unit

Mortality (All ages)

Mortality (30yr + )

Infant Mortality (o-1yr)

Chronic Bronchitis (27yr +)

Bronchitis in children aged 6 to

Respiratory Hospital Admissions (All ages)

Cardiac Hospital Admissions (>18 years)

Restricted Activity Days (all ages)

Asthma symptom days (children 5-19yr)

Lost working days ( $15-64$ years)

$\begin{aligned}-1,156 & \text { Life years lost } \\ -144 & \text { Premature deaths } \\ 0 & \text { Premature deaths } \\ -108 & \text { Cases } \\ -387 & \text { Cases } \\ -53 & \text { Cases } \\ -39 & \text { Cases } \\ -158,050 & \text { Days } \\ -3,467 & \text { Days } \\ -30,886 & \text { Days }\end{aligned}$

\subsection{Climate impact}

The climate impacts of the different scenarios show relatively small variation for the scenarios (Table 17).

Table 17: Scenario-specific climate impacts of small scale wood combustion in Denmark, Finland, Sweden 2035 (ktonne CO2eq). $\mathrm{CH}_{4}$, NMVOC, BC and OC

\begin{tabular}{lllrrr} 
& Activity data & Combustion behaviour (\% bad combustion) & Low & Mid & High \\
& & & kt CO2 eq & \\
SC $_{1}$ & Adapted baseline & Expected (10\%) & 509 & 1,009 & 1,493 \\
SC2 & Adapted baseline & Worse (20\%) & 520 & 1,019 & 1,500 \\
SC 3 & Adapted baseline & Good (0\%) & 499 & 1,000 & 1,487 \\
SC4 & Modern technologies & Expected (10\%) & 472 & 937 & 1,390 \\
SC5 & Modern technologies & Worse (20\%) & 479 & 943 & 1,393 \\
SC6 & Modern technologies & Good (0\%) & 465 & 931 & 1,387 \\
\hline
\end{tabular}

The climate impact variation between the scenarios ( $\left.\mathrm{SC}_{1}-6\right)$ is around $10 \%$ from changed emissions of $\mathrm{CH}_{4}, \mathrm{BC}, \mathrm{NMVOC}$ and $\mathrm{OC}$. These relatively small differences are largely due to that according to the emission calculations for the scenarios black carbon, BC, the pollutant with the highest climate impact (highest GWP, Table 10) differ very little between the emission scenarios (Figure 10). Also, the decrease in emissions of OC (cooling impact) with better technologies and improved combustion behaviour contributes to the relatively modest improvement regarding climate impact.

By comparing specific scenarios we could identify the impact of behaviour ( $\mathrm{SC}_{2}-$ $\mathrm{SC}_{3}$ ) and of improved technologies ( $\left.\mathrm{SC}_{4}-\mathrm{SC}_{1}\right)$. The comparisons show that improved combustion behaviour from $20 \%$ bad ( $\mathrm{SC}_{2}$ ) to good ( $0 \%$ bad, $\mathrm{SC}_{3}$ ) would avoid in the order of $15^{-20}$ ktonnes $\mathrm{CO}_{2}$ eq in 2035 (Table 18). The estimated impact of improved 
technologies, the total reduction in going from $\mathrm{SC}_{1}$ to $\mathrm{SC}_{4}$ is between $37-104$ ktonnes $\mathrm{CO}_{2}$ eq, depending on if the low, mid or high GWP values are used. When comparing the worst scenario, where some old technologies are still in use, and with $20 \%$ bad combustion ( $\left.\mathrm{SC}_{2}\right)$ and the best scenario with only modern stoves and boilers, and all combustion is good ( $0 \%$ bad) ( $\mathrm{SC} 6$ ), the estimated reduced climate impact is between 55-113 ktonnes $\mathrm{CO}_{2}$ eq.

Table 18: Impact on total emissions of poor combustion behaviour, improved technology and the difference between worst and best scenarios 2035 (ktonne CO2eq)

$\begin{array}{rrr}21 & 19 & 13 \\ -37 & -72 & -104 \\ -55 & -88 & -113\end{array}$

The estimated potential climate effect, around $100 \mathrm{ktCO} 2 \mathrm{eq}$, amounts to approximately $0.1 \%$ of projected total greenhouse gas emissions in 2030 from Denmark, Finland and Sweden (emission projections data from national Biennial Reports to UNFCCC, 2015). 



\section{Discussion and conclusion}

The scenario results presented in this work suggests that there is a realistic and technical potential to reduce the adverse health effects and, to some extent, the climate impact from future residential biomass combustion in Denmark, Finland and Sweden by reducing emissions of PM2.5 and SLCPs. The amount of wood combusted in residential biomass equipment, the level of penetration of modern technology and the user behaviour in managing the combustion process all have a significant impact on the emission levels in the three Nordic countries.

There are uncertainties in the underlying data used in the emission inventories for residential biomass combustion. Sufficiently detailed knowledge on the amount and moisture content of biomass used in different combustion technologies is needed, as well as knowledge about the combustion behaviour.

The current activity data collection procedures for residential biomass combustion in the three Nordic countries are presented in this report. There are similarities, but also some significant differences in the national data collection procedures, both regarding the status of knowledge and the type and sources of information available and/or used.

In general for all countries, procedures to regularly update information on technologies and fuel used in these as well as on user behaviour are needed to be able to reflect future changes. For the individual countries needs for future improvements are different and depend on the current status and availability of information.

As the current data collection procedures in the countries have evolved somewhat differently, lessons can be learnt from each other, as appropriate.

In the scenarios developed in this work, available national projections of future biomass fuel consumption in Denmark, Finland and Sweden were aggregated. No assumptions on alternative amounts of biomass fuel use were investigated. The scenarios are based on realistic assumptions on exchange of older combustion devices with modern ones. For example, no maximum feasible technical reduction (MFTR) scenario was developed. The conclusions below are based on results obtained given the assumptions that there will be no change in biomass use compared to national energy scenarios, that there is a replacement of old technologies with modern, covering $10 \mathrm{PJ}$ out of $148 \mathrm{PJ}$ of biomass combusted in 2035 and that the emission factors for modern equipment are representative for conditions in 2035 :

- The estimated potential reduction of PM2.5 emissions would lead to significant reductions in adverse health effects. In the order of 1000 premature deaths would be avoided annually in Europe in 2035 as a result of replacing older boilers and stoves with modern equipment and good combustion behaviour.

- A reduced climate impact resulting from reduced emissions of the short lived climate pollutants $\mathrm{BC}, \mathrm{CH}_{4}$, NMVOC and $\mathrm{OC}$ from residential biomass burning is 
rather modest and more of a positive side effect in addition to the reduced health effects from PM2.5. The potential emission reductions estimated in the scenarios correspond to approximately $0.1 \%$ of the projected greenhouse gas emissions in Denmark, Finland and Sweden in 2030.

- According to current national projections the use of older technology stoves and boilers in Denmark, Finland and Sweden are expected to only account for about $7 \%$ (10 PJ of $148 \mathrm{PJ}$ ) of total residential biomass use in 2035 . The results show that the potential to reduce emissions from residential biomass burning by replacing those older technologies with modern equipment can be significant, in the order of $15 \%$ for $\mathrm{PM}_{2} .5$ and $\mathrm{OC}, 25 \%$ for NMVOC and $7-9 \%$ for $\mathrm{BC}$ and $\mathrm{CH}_{4}$.

- If, in addition to replacement of older equipment, the combustion behaviour is improved from the assumed $90 \%$ up to $100 \%$ of the population having good combustion behaviour, the potential to reduce the emissions rises to $26 \%$ for PM2.5, 32\% for OC, 35\% for NMVOC, $15 \%$ for $\mathrm{CH}_{4}$ and $8 \%$ for $\mathrm{BC}$.

- There are incentives to introduce policies for early scrapping of old devices and replacement to modern equipment. Effective information campaigns to educate users in proper combustion behaviour are also important, since a change in combustion behaviour can have a large effect on emissions.

As wood consumption has a major impact on emission levels, changes in energy scenarios will impact future emission levels. Additional alternative developments, such as different rates of replacement of old with modern equipment, or further technological development towards even lower-emitting combustion equipment would also affect the results. These alternative developments were not included in this study.

In this study the emission factors developed in the Nordic SLCP project were used. The national combustion technology splits used in the national inventories in Denmark, Finland and Sweden were adapted into the split of technology types for which the measurements in the Nordic project were carried out (TN2017:570). The results of this study are complementary to the national projections and emission inventories and are not necessarily consistent with them. One example highlighting this are the large differences in estimated emissions between the national projections with existing measures (WEM) and the scenarios prepared in this study, particularly for $\mathrm{BC}$ and $\mathrm{CH}_{4}$. This is mainly due to sometimes considerable differences between the national emission factors used in the WEM-projections, and the emission factors used in this study. The emission factors in this study are based on the results from the measurement program carried out in the Nordic SLCP project (TN2017:570) covering common, but a limited number of combustion equipment types. There are also other relevant emission factor data sets available that could be considered when analysing the Nordic circumstances. 


\section{Sammanfattning}

Förbränning av biomassa i bostadssektorn är en stor källa till utsläpp av PM2.5 och kortlivade klimatpåverkande luftföroreningar, SLCP (Short Lived Climate Pollutants) i de nordiska länderna. SLCP och PM2.5 har inverkan på klimat, miljö och hälsa. För att utveckla strategier för att minska utsläppen och dess effekter är det viktigt att det finns tillförlitliga uppgifter om nuvarande utsläpp och kunskap om hur de skulle kunna minskas genom lämpliga åtgärder.

I denna rapport presenteras förslag på hur insamlingen av nationella aktivitetsdata som underlag till emissionsinventeringar skulle kunna förbättra. Dessutom presenteras scenariosresultat med beräknade tekniska potentialer för minskade utsläpp av SLCP och PM2.5 från småskalig förbränning av biomassa, omvandlade till potentiell påverkan på hälsa och klimat år 2035.

Arbetet har finansierats av Nordiska Ministerrådets Klimat- och Luftgrupp och kompletterar det större nordiska projektet "Improved emission inventories of ShortLived Climate Pollutants (SLCP)" (Kindbom et al. 2015, Kindbom et al. 2017) som har finansierats av Nordiska Ministerrådet.

Det finns osäkerheter i de underliggande data som används i beräkningar av emissioner till luft från småskalig biomassaförbränning. Det krävs tillräckligt detaljerad information om mängden och fuktinnehållet i bränslet som används i olika förbränningsteknologier, liksom kunskap om användarrelaterade faktorer såsom beteende vid eldning.

Det finns likheter mellan Danmark, Finland och Sverige när det gäller nationell utrustning för småskalig förbränning och användningsmönster, men också några betydande skillnader, utöver förfaranden för insamling av aktivitetsdata. Skillnader relaterade till information om aktivitetsdata ligger huvudsakligen i kunskapsstatus och vilken typ och informationskällor som är tillgängliga och/eller används. Generellt, för alla tre länderna behövs rutiner för regelbunden uppdatering av information om teknik, användarbeteende och bränslemängder som förbränns i varje teknik för att kunna ta fram tillförlitliga utsläppsinventeringar och kunna bedöma framtida förändringar. De nuvarande förfarandena för datainsamling i länderna har historiskt utvecklats på något olika sätt. Beroende på nuvarande olika status kan vi lära av varandras erfarenheter, då målet är detsamma, att kunna ta fram tillräckligt bra data för utsläppsberäkningar.

Scenarioresultaten tyder på att det finns en realistisk och teknisk potential att minska de negativa hälsoeffekterna och till viss del klimatpåverkan från framtida biomassaförbränning i Danmark, Finland och Sverige genom att minska utsläppen av SLCP och PM2.5. Nivån på använda mängder av ved, penetration av modern teknik i biomassförbränning och användarbeteendet vid hantering av förbränningsprocessen har alla betydande effekter på utsläppsnivåerna i de tre nordiska länderna. Resultaten i denna studie visar att: 
- den beräknade potentiella minskningen av PM2.5-utsläpp skulle leda till betydande minskningar av negativa hälsoeffekter. I storleksordningen 1000 förtida dödsfall skulle undvikas årligen i Europa 2035 som ett resultat av att äldre pannor och eldstäder ersattes med modern utrustning och bra förbränningsbeteende;

- den minskade klimatpåverkan som effekt av minskade utsläpp av de kortlivade klimatpåverkande föroreningarna $\mathrm{BC}, \mathrm{CH}_{4}, \mathrm{NMVOC}$ och $\mathrm{OC}$ från biomassaförbränning i bostadssektorn är ganska blygsam och mer att betrakta som positiva bieffekter utöver de minskade hälsoeffekterna från att minska PM2.5-utsläppen. De potentiella utsläppsminskningarna som uppskattas i scenarierna motsvarar ungefär $0.1 \%$ av de prognostiserade utsläppen av växthusgaser från Danmark, Finland och Sverige tillsammans år 2030;

- enligt nuvarande nationella prognoser väntas användningen av äldre teknologier av kaminer och pannor i Danmark, Finland och Sverige bara utgöra ca 7\% (10 PJ av $148 \mathrm{PJ}$ ) av total biomassanvändning år 2035. Resultaten visar att potentialen att minska utsläppen genom att ersätta den äldre tekniken med modern utrustning 2035 kan vara signifikant, i storleksordningen $15 \%$ för PM2.5 och OC, $25 \%$ för NMVOC och 7-9\% för BC och $\mathrm{CH}_{4}$;

- om förutom utbyte av äldre utrustning även förbränningsbeteendet förbättras, från de antagna 90\% upp till att 100\% av befolkningen har bra förbränningsbeteende, ökar potentialen att minska utsläppen till 26\% för PM2,5, $32 \%$ för OC, $35 \%$ för $\mathrm{NMVOC,} 15 \%$ för $\mathrm{CH}_{4}$ och $8 \%$ för $\mathrm{BC}$;

- det finns incitament att införa policies för tidig skrotning av gamla enheter och ersätta med modern utrustning. Effektiva informationskampanjer för att utbilda användare i korrekt förbränningsbeteende är också viktiga, eftersom en lyckad förändring av förbränningsbeteendet kan få stor effekt på utsläppen.

Alternativa utvecklingar, speciellt i totala mängden använd biomassa, skulle få stor effekt på de resulterande utsläppen. Ytterligare alternativa utvecklingar, till exempel olika takt på ersättning av gammal med modern utrustning, eller teknisk utveckling mot förbränningsutrustning med ännu lägre emissioner skulle också påverka resultatet.

I den här studien användes de emissionsfaktorer som utvecklades i ett mätprogram som var en del av det nordiska SLCP-projektet (TN2017: 570). Den nationella fördelningen på typ av förbränningsutrustning som används i de nationella inventeringarna i Danmark, Finland och Sverige anpassades till $n$ uppdelning enligt de teknologityper på vilka mätningar i det nordiska projektet genomfördes. Resultaten av denna studie kompletterar de nationella prognoserna och emissionsberäkningarna och är inte nödvändigtvis jämförbara med dem. 


\section{References}

ACAP (2014). Reduction of Black Carbon Emissions from Residential Wood Combustion in the Arctic - Black Carbon Inventory, Abatement Instruments and Measures. Arctic Contaminants Action Program (ACAP). 164 pp. ISBN 978-82-999755-01-36.

Amann M. (2012) The GAINS Integrated Assessment Model - EC4MACS Modelling Methodology.

Bickel, P. and R. Friedrich (2005). ExternE Externalities of Energy - Methodology 2005 update.

EEA (2016) EMEP/EEA Air Pollutant Emission Inventory Guidebook 2016.

https://www.eea.europa.eu/publications/emep-eea-guidebook-2016

Energimyndigheten (2017). Scenarier över Sveriges energisystem 2016. ER2017:06.

Gustafson, T. and Helbig, T. (2017). Förbättrade nationella beräkningsunderlag för utsläpp av $\mathrm{PM} 2,5, \mathrm{BC} / \mathrm{EC}, \mathrm{OC}, \mathrm{CH}_{4}$, NMVOC och CO från småskalig biobränsleeldning. (In Swedish). PM 2017-12-06 to the Swedish EPA.

Holland M. et al. (2012) The Alpha Benefit Assessment Model - EC4MACS Modelling Methodology.

IPCC (2013) Climate Change 2013: The Physical Science Basis. Contribution of working group I to the fifth assessment report of the Intergovernmental Panel on Climate Change, Chapter 8: Anthropogenic and Natural Radiative Forcing.

Kindbom, K., Fridell, E., Skårman, T., Nielsen, O.-K., Winther, M., Saarinen, K., Lappi, M., Lamberg, H., Kolka Jónsson, P. V., Aasestad, K. (2015). Improved emission inventories of SLCP - Background analysis. TemaNord TN2015:523. http://norden.divaportal.org/smash/record.jsf?pid=diva2\%3A807348\&dswid=-9909

Kindbom, K., Mawdsley, I., Nielsen, O.-K., Saarinen, K., Jonsson, K., Aasestad, K. (2017). Emission factors for SLCP emissions from residential wood combustion in the Nordic countries. TemaNord TN2017:570. http://norden.divaportal.org/smash/record.jsf?pid=diva2\%3A1174670\&dswid=-4245

National Biennial reports (2015).BR2 from Denmark, Finland and Sweden.

http://unfccc.int/national_reports/national_communications_and_biennial_reports/submissio ns/items/7550.php

Paulrud, S., Kindbom, K., Gustafsson, T. (2006). Emission factors and emissions from residential biomass combustion in Sweden. SMED Report No 34 2010. http://www.smed.se/wpcontent/uploads/2011/05/SMED_Report_2010_34.pdf

Savolahti M., Karvosenoja N., Kupiainen K. 2014. Ecodesign directive for residential wood combustion appliances: Impacts and emission reduction potential in Finland. The Sustainable City IX Vol. 2, WIT

Savolahti M., Karvosenoja K., Kupiainen, Paunu 2015. Pienpolton päästövähennyskeinojen kustannustehokkuus ja vaikutukset väestöaltistukseen. Raportti 2/2/2015. (In Finnish)

Savolahti, M., Karvosenoja, N., Kupiainen, K., Paunu, V-V. (2015). Cost efficiency of wood combustion emission reduction measures and impacts on population exposure. Puunpolton päästövähennyskeinojen kustannustehokkuus ja vaikutukset väestöaltistukseen. Suomen Ympäristö 2/2/2015 . 18 pages I(in Finnish) Transactions on Ecology and The Environment, Vol 191, pp. 1493-1504. doi:10.2495/SC141272.

Savolahti, M., Karvosenoja, N., Tissari, J., Kupiainen, K., Sippula, O., Jokiniemi, J. (2016) Black carbon and fine particle emissions in Finnish residential wood combustion: Emission projections, reduction measures and the impact of combustion practices. Atmosperic Environment 140: 495-505 (2016). 
Todorovic, J., Broden, H., Padban, N., Lange, S., Gustafsson, L., Johansson, L., Paulrud, S., Löfgren, B.-E. (2007). Syntes och analys av emissionsfaktorer för småskalig biobränsleförbränning. (Synthesis and assessment of emission factors for small scale biomass combustion). In Swedish, English summary. Final report for contracts 5030506 and 5030507 from the Swedish Environmental Protection Agency.

UEF (2011) University of Eastern Finland, PUPO Database on Small Combustion, Emissions and Toxicity. https://www.uef.fi/en/web/fine/pupo-database (in Finnish).

UNITED NATIONS 2011. World Population Prospects The 2010 Revision - Volume I: Comprehensive Tables. New York: United Nations.

WHO 2013. Health risks of air pollution in Europe - HRAPIE project: Recommendations for concentration-response functions for cost-benefit analysis of particulate matter, ozone and nitrogen dioxide. 
Nordic Council of Ministers

Nordens Hus

Ved Stranden 18

DK-1061 Copenhagen K

www.norden.org

Potentials for reducing the health and climate impacts of residential biomass combustion in the Nordic countries

Residential biomass combustion is a major source of PM2.5 and SLCP (Short Lived Climate Pollutants) emissions in Denmark, Finland and Sweden. SLCPs and PM2.5 have impact on climate, environment and health. When developing strategies for reduced emissions, reliable information on current emissions and assessments for how they can be reduced is essential.

This report presents recommendations for how to further improve national activity data collection procedures for less uncertain emission inventory results. It also presents scenario results with estimated technical potentials for reduced emissions of SLCPs and PM2.5 from residential biomass combustion, transformed into potential impact on health and climate effects in 2035 . 